\title{
EESTI MÕTTELOO UURIMINE 21. SAJANDIL
}

\author{
Pärtel PIIRIMÄE \\ Tartu Ülikool, humanitaarteaduste ja kunstide valdkond, filosoofia ja semiootika instituut, Ülikooli 18, \\ 50090 Tartu, Eesti; partel.piirimae@ut.ee \\ Artikli eesmärgiks on anda ülevaade mõtteloo uurimisest Eestis 21. sajandi esimestel kümnenditel. \\ Et paremini mõista mõtteajaloo või intellektuaalajaloo hetkeseisu, heidetakse artiklis pilk selle eelloole \\ Eestis avant la lettre ehk enne valdkonna distsiplinaarset emantsipeerumist ning vaadeldakse lühidalt \\ valdkonna tähtsamaid arengusuundi mujal maailmas 20. sajandil ja 21. sajandi algul. Sellel taustal \\ eritletakse peamisi meetodeid ja žanre, mida on viimastel aastakümnetel kasutatud mõtteloo uurimisel \\ Eestis, arutletakse eri käsitlusviiside eeliste ja puuduste üle ning võetakse kõne alla võimalikud eda- \\ sised uurimisperspektiivid.
}

\section{MÕTTELOO UURIMISTRADITSIOONIST EESTIS}

Erinevalt mitmest teisest ajaloo valdkonnast - medievistika, sotsiaalajalugu, majandusajalugu jt - puudub ideede- või mõtteajalool Eestis selgepiiriline identiteet ja pikaajaline uurimistraditsioon, millele praegused uurijad saaksid toetuda või millega kriitiliselt suhestuda. 21. sajandi algust võibki pidada mõtteajaloo kui eraldiseisva teadusvaldkonna sünniperioodiks Eestis. See ei tähenda, et Eestis ei oleks mõttelugu varem üldse käsitletud või selle süstemaatilisema uurimise vajadust teadvustatud. Me saame rääkida ajalooliste ideede uurimise vähemalt sajandipikkusest traditsioonist, aga see on alati jäänud teiste distsipliinide äärealadele ega ole moodustanud ühtse nimetajaga tervikut.

Valdkonna distsiplinaarne marginaalsus 20. sajandi Eestis torkab iseäranis silma võrdluses muu maailmaga, eriti naaberriigi Rootsiga, kus ideede- ja teadusajalugu (idé- och lärdomshistoria) institutsionaliseerus iseseisva uurimisvaldkonnana juba 1930. aastatel. Ka tänapäeval globaalselt mõjukaimas angloameerika teaduskultuuris hakkas ideedeajalugu (history of ideas) emantsipeeruma juba enne Teist maailmasõda. Alates 1960. aastatest saame rääkida ideedeajaloost välja kasvanud intellektuaalajaloo (intellectual history) ja poliitilise mõtte ajaloo (history of political thought) tormilisest arengust, mis väljendus nii metodoloogilises reflektsioonis kui ka uudsete meetoditega tehtud süstemaatilises uurimistöös. 
Eestis oli sõjaeelsel ajal huvi rahvusliku mõtteloo vastu küll selgelt olemas, ent ajalooteaduslik kultuurikiht veel liiga õhuke, et sellelt pinnalt saanuks tekkida eraldiseisev valdkond. Sõjajärgsetel okupatsiooniaastatel takistas mõtteloo uurimist veelgi enam kui teiste ajaloovaldkondade puhul - „teadusliku“ marksismi-leninismi õpetuse kuulutamine ainumõeldavaks ühiskonnatõlgenduse skeemiks, mille vaatepunktist lähtudes tuli hinnata (ja eriti muidugi ,ümber hinnata“) ka ajalooliste mõtlejate ideid. ${ }^{1}$ Nõukogude Liidust imporditi kiirelt ideoloogilised põhimõisted, mille alusel ühiskondlik-poliitilised ideed jaotati klassipõhiselt progressiivseteks-revolutsioonilisteks ja tagurlikeks-reaktsioonilisteks suundadeks. ${ }^{2}$ Nende mõtlejate kaanon, kelle käsitlemisele oli lubatud nõukogude teadlase ajaressurssi kulutada, oli piiratud selle ideoloogia alusel määratud positiivsete kangelastega ehk ajalooliste tegelastega, keda oli võimalik paigutada imaginaarse üleajaloolise klassivõitluse Prokrustese sängis õigele poolele. ${ }^{3}$ Nii oli küll võimalik uurida näiteks Kreutzwaldi või Jakobsoni kui „demokraatlik-talupoeglike“ mõtlejate töid seotuna nende ühiskondliku tegevusega ning tuua üksikasjade osas arhiivitöö põhjal välja ka uudset ja väärtuslikku faktimaterjali, ${ }^{4}$ ent nende ideede (või tollases kõnepruugis ,,maailmavaate") tõlgendamisel, mis on ometigi intellektuaalajaloo peamine sisu ja eesmärk, oli valitseva ideoloogia etteantud mänguruum ja sõnavara võrdlemisi kitsas. ${ }^{5}$ Kui mitmetes teistes ajaloo valdkondades oli „eessõnaleninismi“ ja retooriliste kummarduste varjus võimalik mõnevõrra vabamalt toimetada, siis mõtteajalugu oli selleks liiga ideoloogiliselt laetud. ${ }^{6}$

Nii leiti end taasiseseisvumise järgselt olukorrast, kus muu maailma ideedeajalugu ei uuritud ega õpetatud ning Eesti mõtteloo uurimises oli suur tühimik, mida kiirelt oli võimalik täita vaid sõdadevahelise vabariigi aegsete tõlgendusskeemide juurde tagasi pöördudes, need aga olid oma metodoloogilises natsionalismis ja ideelises

1 Nagu Andrus Tool rõhutab, oli marksistliku filosoofia ülesandeks mitte arutlemine, vaid hinnangu andmine. Tool, A. Filosoofiline teadmiskultuur Eestis aastail 1946-1991. - Tagasi mõteldes: Töid filosoofia ajaloost Eestis. Koost Ü. Matjus. Tartu Ülikooli Kirjastus, Tartu, 2016, 279. Vt ka Loone, E. Eesti filosoofia eesti kultuuris pärast II maailmasõda. - Eesti filosoofia: mis see on? Toim H. Eenmaa. SE\&JS, Tallinn, 15-42.

2 Naan, G. Eesti kodanlike natsionalistide ideoloogia reaktsiooniline olemus. Poliitiline Kirjandus, Tallinn, 1947; Naan, G. Proletaarne internatsionalism ja kodanlik natsionalism. Eesti Riiklik Kirjastus, Tallinn, 1950. Vt ka Undusk, J. Retooriline sund eesti nõukogude ajalookirjutuses. - Võim ja kultuur. Koost A. Krikmann, S. Olesk. Eesti Kirjandusmuuseum, Tartu, 2003, 41-68.

3 Uurimisteemade valiku ja kinnitamise protsess nõukogude aja teadusasutustes vajaks eraldi uurimist.

4 Nt Jansen, E. C. R. Jakobsoni „Sakala“. Eesti Raamat, Tallinn, 1971; Jansen, E. Carl Robert Jakobson muutuvas ajas: Märkmeid, piirjooni, mõtteid. Eesti Raamat, Tallinn, 1987; Põldmäe, R. C. R. Jakobsoni teedest ja töödest. Eesti Raamat, Tallinn, 1985.

5 Nii peab Kreutzwaldi maailmavaadet käsitlev Ea Jansen otsima Kreutzwaldi maailmapildist materialismi, ateismi, dialektika ja klassivõitluse sugemeid ning nentima, et Kreutzwaldi ei jõudnud „järjekindla materialismini“ ja „revolutsioonilise võitluse vajalikkuse mõistmisele“ (Jansen, E. Kreutzwald kui valgustaja-demokraat. - Fr. R. Kreutzwaldi maailmavaade ja tegevus. Koost G. Naan. Eesti Riiklik Kirjastus, Tallinn, 1953, 7-35), samamoodi ei jõudnud Jakobson ,teadusliku sotsialismini“ (Jansen, E. Carl Robert Jakobson muutuvas ajas, 48).

6 „Eessõnafilosoofia“ kohta vt: Mölder, B. Marksistlik vaimufilosoofia Nõukogude Eestis. - Tagasi mõteldes, 333; Loone, E. Eesti filosoofia ida ja lääne piiril. - Studia Philosophica, 1993, 1 (37), 129-155. 
skemaatilisuses samuti ajale jalgu jäänud. ${ }^{7}$ Võib-olla veelgi suurem probleem valdkonna arengu seisukohalt oli nõukogude perioodist päritud ja enamasti teadvustamata arusaam selle kohta, mis rolli ideed üldse ajaloos mängivad, ning sellest tulenev hinnang ideedeajaloo kui uurimisvaldkonna autonoomia kohta. Marksistlikus ajaloofilosoofias olid ajaloo liikumapanevateks jõududeks materiaalsed suhted ning ideed olid taandatud tootmissuhetest tingitud klassiteadvusele. Seega oli ajalooprotsessi mõistmiseks oluline uurida majanduslikke ja sotsiaalseid suhteid, mitte ideid, millele jäi kitsas ideoloogiline funktsioon. ${ }^{8}$ 1990. aastatel mõistagi loobuti rangest sotsioökonoomilisest reduktsionismist ning taastati selle kõrval poliitilise sfääri autonoomia, ent sel perioodil kavandatud üldkäsitlustest nähtub, et ideid käsitleti jätkuvalt justkui kõrvalsaadusena tegelike ajalugu kujundavate jõudude kõrval. ${ }^{9}$

Sellegipoolest andsid 1990. aastad tugeva tõuke mõtteajaloolisele uurimistööle, mille tulemusel on see valdkond nüüdseks teiste ajaloovaldkondade kõrval tunnustust leidnud, millest annab tunnistust ka eraldi peatükk käesolevas teemanumbris. Me saame kõnelda vähemalt neljast tegurist, mis mõtteajaloo emantsipeerumist soodustasid. Esiteks said tsensuurivabas õhkkonnas oma uurimistööd jätkata professionaalsed ajaloolased, kes juba nõukogude perioodil olid alustanud ideedemaailma uurimist vastavalt tollastele võimalustele. Nende seas tuleks esmalt nimetada ENSV Teaduste Akadeemia Ajaloo Instituudi (hiljem Tallinna Ülikooli ajaloo instituudi) koolkonda eesotsas Ea Janseni ja Toomas Karjahärmiga, kelle teadustööd on olnud mõõduandvad 19. sajandi teise poole ja 20. sajandi esimese poole uurimisel. Kui Janseni käsitlusviisi võib nimetada sotsiokultuuriliseks, mis keskendub pigem mõtteloo taustaks olnud ühiskondlik-kultuurilisele arengule, ${ }^{10}$ siis Karjahärm on viljelenud ideede- või mõtteajalugu selle sõna kitsamas tähenduses, ${ }^{11}$ süstematiseerides,

7 Nt Laar, M., Vahtre, L., Valk, H. Kodu lugu I-II. (Loomingu Raamatukogu, 40/41-42/43.) Perioodika, Tallinn, 1989.

8 Ideed olid peamiselt sotsiaalmajanduslike suhete vahetuks peegelduseks (Naan, G. Friedrich Reinhold Kreutzwald. - Fr. R. Kreutzwaldi maailmavaade ja tegevus, 3-6), aga rõhutati ka „individuaalse loovisiksuse" rolli ajaloolise progressi kiirendajana (Jansen, E. Carl Robert Jakobson muutuvas ajas, 10).

9 Eesti ajaloolaste koostatud „Eesti ajaloo“ üldkäsitluses on ideede maailm enamasti taandatud „vaimueluks“, mis on poliitiliste sündmuste ja sotsiaalmajanduslike tegurite poolt käivitatud ajalooprotsessi juures justkui garneering, mitte sündmusi endid mõjutanud jõud. Neljandas köites (Eesti ajalugu IV: Põhjasõjast pärisorjuse kaotamiseni. Peatoim S. Vahtre. Ilmamaa, Tartu, 2003) on näiteks pärisorjuse kaotamise küsimust käsitletud enne „vaimuelu“ peatükki, mis jätab mulje ideeliste tegurite sekundaarsusest pärisorjuse teema juures. Viiendas köites (Eesti ajalugu V: Pärisorjuse kaotamisest Vabadussõjani. Peatoim S. Vahtre. Ilmamaa, Tartu, 2010) puuduvad eraldi mõttelugu käsitlevad peatükid. Rahvusliku „ärkamise“ ja „liikumise“ ülevaate fookuses on aktivism, kavad ja programmid, aga mitte neid selgitavad ideed või filosoofiline maailmavaade.

${ }^{10}$ Jansen, E. Vaateid eesti rahvusluse sünniaegadesse: Artiklikogu. Ilmamaa, Tartu, 2004; Jansen, E. Eestlane muutuvas ajas: Seisuseühiskonnast kodanikuühiskonnani. Eesti Ajalooarhiiv, Tartu, 2007. Vt ka Piirimäe, E. Eesti rahvuslus Euroopa kontekstis. - Ajalooline Ajakiri, 2007, 119, 1, 93-109.

${ }^{11}$ Karjahärmi sulest leiab ka ideeajaloo ehk mõtteloo määratluse, mis toetub peamiselt Markku Hyrkkänenile, kes on rõhutanud mõtlemise ja tegutsemise olemuslikku seotust: Karjahärm, T. Vaim ja võim: Eesti haritlaskond 1917-1940. Argo, Tallinn, 2001, 215; Hyrkkänen, M. Ideeajaloo mõte. Tlk M. Kivine. - Akadeemia, 1990, 12, 2555-2576. 
kirjeldades ja analüüsides oma teostes Eesti haritlaste ühiskondlik-poliitilisi ideid. ${ }^{12}$ Siia nimekirja tuleks lisada Ajaloo Instituudis karjääri alustanud noorema põlvkonna ajaloolane Indrek Jürjo, kes oma enneaegselt lõppenud loometöö jooksul jõudis produktiivselt uurida Balti provintside valgustusaegset kultuuri- ja mõttelugu. ${ }^{13} \mathrm{Jär}-$ jepidevalt mõtteloo uurimisse panustanud teaduskeskuseks on olnud ka Tartu Ülikooli raamatukogu, kus juba alates 1970. aastatest on raamatukogu varade toel uuritud varauusaja teadus- ja haridusajalugu. Arvo Teringu pikaajalist tööd Balti provintside üle-euroopaliste akadeemiliste kontaktide, tudengite õpirände, teaduslike mõjutuste ja ideede retseptsiooni uurimisel ${ }^{14}$ on raamatukogu teaduskeskuses jätkatud alates 21 . sajandi algusest projektipõhisel kujul. ${ }^{15}$

Teiseks sai taasiseseisvunud Eestis hariduse uus põlvkond ajaloolasi, kes tundsid huvi ideedeajaloo vastu ja tajusid selle valdkonna senist nõrka esindatust Eesti akadeemilisel maastikul. Kohaliku õpetamistraditsiooni puudumisel läksid mitmed

${ }^{12}$ Karjahärm, T. Tõuküsimus Eestis iseseisvuse eel: Historiograafiline referaat. - Akadeemia, 1993, 7, 1347-1364; Karjahärm, T. Eurooplus, eestlus ja „Noor-Eesti“. - Akadeemia, 1994, 9, 1795 1821; Karjahärm, T. Eesti liberalismi ajaloost. - Looming, 1995, 12, 1675-1687; Karjahärm, T. Eesti rahvusluse ideed. - Akadeemia, 1995, 10, 2051-2077; Karjahärm, T., Sirk, V. Eesti haritlaskonna kujunemine ja ideed 1850-1917. Eesti Entsüklopeediakirjastus, Tallinn, 1997; Karjahärm, T. Ida ja lääne vahel: Eesti-vene suhted 1850-1917. Eesti Entsüklopeediakirjastus, Tallinn, 1998; Karjahärm, T., Sirk, V. Vaim ja võim: Eesti haritlaskond 1917-1940. Argo, Tallinn, 2001; Karjahärm, T. Eesti intellektuaalide Euroopa identiteet 20. sajandi esimesel poolel. - Acta Historica Tallinnensia, 2001, 5, 45-74; Karjahärm, T. Unistus Euroopast. Argo, Tallinn, 2003; Karjahärm, T., Sirk, V. Kohanemine ja vastupanu: Eesti haritlaskond 1940-1991. Argo, Tallinn, 2007.

${ }^{13}$ Jürjo, I. Liivimaa valgustaja August Wilhelm Hupel 1737-1819. Riigiarhiiv, Tallinn, 2004; Jürjo, I. Ideed ja ühiskond. Balti provintside mõtte- ja kultuuriloost 18.-19. sajandil. Koost I. Põltsam-Jürjo, T. Tannberg. Eesti Ajalooarhiiv, Tartu, 2011.

${ }^{14}$ Tering, A. Descartes ja tema ideede jõudmine Baltimaile 17. sajandil ja 18. sajandi algul. TÜ Raamatukogu, Tartu, 1996; Tering, A. Tartu teadussidemed Saksamaaga 18. sajandil. - Tartu, baltisakslased ja Saksamaa: Artiklite kogumik. Koost H. Piirimäe ja C. Sommerhage. Tartu Ülikooli Kirjastus, Tartu, 1998, 53-72; Tering, A. Heliotsentrilisest maailmasüsteemist ja selle retseptsioonist Baltimail 17. sajandil. - Läänemere provintside arenguperspektiivid Rootsi suurriigis 16/17. sajandil. Koost K. Tafenau. (Eesti Ajalooarhiivi toimetised, 12.) Eesti Ajalooarhiiv, Tartu, 2006, 151-199; Tering, A. Eesti-, liivi- ja kuramaalased Euroopa ülikoolides 1561-1798. Eesti Ajalooarhiiv, Tartu, 2008; Tering, A. Zur frühen Rezeption von Harveys Theorie des Blutkreislaufs im deutschen Sprachraum: Eine apologetische Disputation in Königsberg aus dem Jahre 1651. - Dichtung Gelehrsamkeit - Disputationskultur: Festschrift für Hanspeter Marti zum 65. Geburtstag. Hrsg. v. R. B. Sdzuj, R. Seidel, B. Zegowitz. Böhlau, Wien, Köln, Weimar, 2012, 461-481; Tering, A. Skorbuuditeema Baltimaade arstide dissertatsioonides varasel uusajal. - Ajalooline Ajakiri, 2013, 4, 143, 447-464; Tering, A. Uute füsioloogiaideede retseptsioonist Baltimaade meedikute väitekirjades 17. sajandi viimasel veerandil. - Kroonikast epitaafini: Eesti- ja Liivimaa varauusaegsest haridus- ja kultuurielust. Koost K. Kaju. (Acta et commentationes archivi nationalis estoniae, 1 (32).) Rahvusarhiiv, Tartu, 2017, 239-270; Tering, A., Beyer, J. Lexikon der Studenten aus Estland, Livland und Kurland an europäischen Universitäten 1561-1800. Böhlau, Köln, 2018.

${ }^{15}$ SF0180040s08 „Ideede ja teooriate levik ja retseptsioon Baltimaades Rootsi ja Vene võimuperioodil (17. saj - 20. saj algus) (juht Pärtel Piirimäe, 2008-2013)“, ETF8205 „Vesimärgid ja paberi ajalugu varauusaegses Eestis“ (juht Meelis Friedenthal, 2010-2013), ETF8938 „Euroopa ülikoolid Eesti-, Liivi- ja Kuramaa arstide koolitajaina ning arsti- ja loodusteaduslike ideede vahendajaina varasel uusajal“ (juht Pärtel Piirimäe, 2011-2014), MP1RT17012 „Helleno-Nordica: humanistide kreeka keel Rootsi suurrriigis“ (juht Janika Päll, 2017-2020). 
neist magistri- ja/või doktorikraadi omandama rahvusvahelistesse intellektuaalajaloo uurimise keskustesse, nagu Cambridge'i Ülikool, ${ }^{16}$ Euroopa Ülikooli Instituut Firenzes ${ }^{17}$ või Lundi Ülikool. ${ }^{18}$ Mõjutatuna sealsetest uurimistraditsioonidest ja -meetoditest on nad Eestisse naasnuna või koostöös Eesti teadlastega käivitanud mõtteajaloolisi uurimisprojekte ning aidanud kaasa valdkonnale institutsionaalse aluse rajamisele Eesti ülikoolides. ${ }^{19}$

Kolmandaks on paljudes humanitaarteadustes ja ajaloo eriharudes toimunud nihe intellektuaalajaloolist laadi teemade suunas ning ka seniseid uurimisteemasid on hakatud paigutama avaramasse mõtteloolisse konteksti. Seda arengut on mõjutanud viimaste aastakümnete muutused rahvusvahelises teaduses, kus enamjaolt on loobutud tänapäeva teadusdistsipliinide „eelloo“ jutustamisest, sest see on sageli viinud anakronistlike küsimuseasetuste ja teleoloogiliste tõlgendusskeemideni. Intellektuaalajalooline ehk kontekstuaalne vaatenurk lähtub uuritava perioodi arusaamast teaduse olemuse ja distsiplinaarse jaotuse kohta, ${ }^{20}$ mitte tänapäeva teaduse klassifikatsioonist ja institutsionaalsest korraldusest. Lisaks on distsipliinide valgumist üle oma seniste piiride ning interdistsiplinaarset koostööd kõrvalseisvate valdkondadega soodustanud 21. sajandi alguses jõuliselt juurutatud projektipõhine teadusuuringute rahastamise mudel. Tulenevalt intellektuaalajaloo loomupärasest interdistsiplinaarsusest on mõtteloo-alased teemapüstitused nii mõnelgi korral pakkunud sobiva katuse erinevate idee- ja teadusajalooga tegelevate valdkondade ühendamiseks.

Ammendatavat ülevaadet kõigist neist humanitaarteaduste valdkondadest, mille puhul võib märgata nihet intellektuaalajalooliste küsimuseasetuste ja meetodite suunas, on võimatu anda - ja tulenevalt distsiplinaarsete piiride hägustumisest ei ole võimalik ega ka vajalik iga teadlast või teost vastavalt lahterdada. Üheks valdkonnaks, mille puhul selget piiri intellektuaalajalooga on järjest keerulisem tõmmata, on kirjandusteadus. Nii mujal maailmas kui ka Eestis on nähtav kirjandusteaduse taustaga teadlaste kasvav huvi poliitilise ja õigusliku mõtte ajaloo vastu, mistõttu lisaks ilukirjanduslike tekstide laiemale kontekstuaalsele analüüsile on laiendatud allikabaasi mitteilukirjanduslike tekstidega ${ }^{21}$ Eestis on teerajajaks

${ }^{16}$ Piirimäe, E. Thomas Abbt (1738-1766) and the philosophical genesis of German nationalism. Cambridge University, 2006; Piirimäe, P. The just war in theory and practice: Legitimations of Sweden's conflicts during the Great Power period. Cambridge University, 2007.

${ }^{17}$ Keedus, L. Omitted encounters: The early political thought of Hannah Arendt and Leo Strauss. European University Institute, Firenze, 2010.

${ }^{18}$ Savin, K. Fortunas klädnader: lycka, olycka och risk i det tidigmoderna Sverige. Lund: Sekel, 2011.

${ }^{19}$ Viimase kümne aasta jooksul on loodud vähemalt kolm ametikohta, mille põhisisuks on intellektuaalajaloo uurimine ja õpetamine: Tartu Ülikoolis Johan Skytte instituudi poliitikateooria dotsent (alates 2014, Eva Piirimäe) ning filosoofia ja semiootika instituudi mõtteloo professor (alates 2018, Pärtel Piirimäe); Tallinna Ülikoolis poliitikafilosoofia professor (alates 2018, Liisi Keedus). Lisaks on Tartu Ülikooli raamatukogu teaduskeskuses loodud intellektuaalajaloo vanemteaduri ning filosoofia ja semiootika instituudis mõtteloo vanemteaduri ametikoht (alates 2020, Meelis Friedenthal).

${ }^{20}$ Vt Friedenthal, M., Piirimäe, P. Philosophical disputations at the University of Tartu 1632-1710: Boundaries of a discipline. - Studia Philosophica Estonica, 2015, 8, 2, 65-90.

${ }^{21}$ Nt Mighty Europe 1400-1700: Writing an early modern continent. Ed. by A. Hiscock. Peter Lang, Oxford, Bern, 2007; Warren, C. N. Literature and the law of nations, 1580-1680. Oxford University Press, Oxford, 2015. 
olnud Jaan Undusk, kes ei ole piirdunud kirjanduslooliste ja -teoreetiliste teemadega, vaid on alates 1990. aastate algusest käsitlenud laia diapasooni ühiskondlik-poliitilisi ja ajaloofilosoofilisi ideid baltisaksa ja eesti autorite teostes. ${ }^{22} \mathrm{Nagu}$ hiljuti ilmunud koguteose „Baltisaksa kirjakultuuri poliitilised dimensioonid“ koostajad rõhutavad, ,ei oma poliitilist mõõdet üksnes ajalookirjutus ja publitsistika, vaid ka kirjandus ja luule“. ${ }^{23}$ Näite edukast koostööst intellektuaalajaloo ja kirjandusteaduse vahel pakub sel aastal ilmunud esinduslik kogumik J. G. Herderi poliitika-, moraali- ja ajaloofilosoofiast. ${ }^{24} \mathrm{Ka}$ Eesti klassikaliste filoloogide uurimisprojektid ja teadustööd Läänemere regiooni õpetlaskultuurist mahuvad oma küsimuseasetuste ja meetodite poolest intellektuaalajaloo alla. ${ }^{25}$ Samamoodi tegelevad ajalooliste ideede kontekstuaalse uurimisega õigusajaloolased, ${ }^{26}$ tea-

${ }^{22} \mathrm{Nt}$ Undusk, J. „Esimene Eesti juudiõgija“: A. Grenzsteini endatapp antisemitismis. - Vikerkaar, 1991, 2, 66-74; 3, 57-68; Undusk, J. Eesti kui Belgia: viimane baltlane Hermann Keyserling. Tuna, 2003, 2, 48-71; lisa 71-78; Undusk, J. Retooriline sund eesti nõukogude ajalookirjutuses; Undusk, J. Das baltische Pantheon in der Naturphilosophie: Baer, Uexküll, Ostwald und das Problem der Zeit. - Umweltphilosophie und Landschaftsdenken im baltischen Kulturraum = Environmental Philosophy and Landscape Thinking. Hrsg. v. L. Lukas, U. Plath, K. Tüür, J. Undusk. (Collegium litterarum, 24.) Underi ja Tuglase Kirjanduskeskus, Tallinn, 2011, 112-136. Undusk, J. Naturrecht und Naturgeschichte im politischen Denken. G. H. Merkel und C. G. Jochmann als Vertreter der aufklärerischen Naturrhetorik. - Aufklärer im Baltikum: Europäischer Kontext und regionale Besonderheiten. Hrsg. v. U. Kronauer. (Akademiekonferenzen, 12.) Winter Universitätsverlag, Heidelberg, 2011, 57-84.

${ }^{23}$ Lukas, L., Schwidtal, M., Undusk, J. Recht und Gesetz, Herrschaft und politische Partizipation: Zur Einführung. - Politische Dimensionen der deutschbaltischen literarischen Kultur. Hrsg. v. L. Lukas, M. Schwidtal, J. Undusk. LIT Verlag, Berlin, 2018, 7-14.

${ }^{24}$ Herder on Empathy and Sympathy: Einfühlung und Sympathie im Denken Herders. Ed. by E. Piirimäe, L. Lukas, J. Schmidt. (Brill's studies in intellectual history, 311.) Brill, Leiden, Boston, 2020.

${ }^{25}$ Näited projektidest: „Reassembling the republic of letters, 1500-1800: A digital framework for multi-lateral collaboration on Europes intellectual history“ (juht Kristi Viiding, 2014-2018); „Humanismi kõrgaeg Liivimaal: David Hilcheni epistolaarpärand keele-, kirjandus-, õigus- ning haridusajaloo allikana“ (juht Kristi Viiding, 2016-2019); „Antiigiretseptsioon ja selle osa Eesti keeleja kultuuriruumi kujunemises 17.-20. saj“ (juht Ivo Volt, 2009-2013). Publikatsioonid: SiimetsGross, H., Viiding, K. The reflection of the Polish legal system in the beginning of 17 th century in the letters and poems of a Livonian humanist David Hilchen. - KUL Journal of Legal Studies (ilmumas); Päll, J. Greek disputations in German and Swedish universities and academic gymnasia in the 17th and early 18th century. - Early modern disputations and dissertations in an interdisciplinary and European context. Ed. by H. Marti, R. Seidel, M. Friedenthal. (Intersections.) Brill, Leiden, Boston (ilmumas).

${ }^{26}$ Mõned näited teostest, mida saaks paigutada laiemalt defineeritud mõtteajaloo alla: Luts, M. Kui neid kapitulatsioone ees ei oleks ...? ehk: Õiguse moderniseerimise takistused Vene impeeriumi Läänemere-provintsides 19. sajandil. - Vene aeg Eestis: uurimusi 16. sajandi keskpaigast kuni 20. sajandi alguseni. Koost T. Tannberg. (Eesti Ajalooarhiivi toimetised, 14 (21).) Eesti Ajalooarhiiv, Tartu, 2006, 24-80; Mälksoo, L. Rahvusvaheline õigus Eestis: ajalugu ja poliitika. Juura, Tallinn, 2008; Mälksoo, L. The liberal imperialism of Friedrich (Fyodor) Martens (1845-1909). - Select proceedings of the European Society of International Law I: Paris, Sorbonne University, April 2006. Ed. by H. R. Fabri, E. Jouannet, W. Tomkiewicz. Hart Publishing, Oxford, 2008, 173-180; Iganenud või igavene? Tekste kaasaegsest suveräänsusest. Toim H. Kalmo, M. Luts-Sootak. Tartu Ülikooli Kirjastus, Tartu, 2010; Luts-Sootak, M. Die baltischen Kapitulationen von 1710 und die Gesetzbücher des 19. Jahrhunderts. - Die baltischen Kapitulationen von 1710. Hrsg. v. K. Brüggemann, 
dusajaloolased ${ }^{27}$ meditsiiniajaloolased ${ }^{28}$ religiooniajaloolased ${ }^{29}$ ja kunstiajaloolased, ${ }^{30}$ kes tänapäeval paiknevad laiali eri teaduskondades, ent kelle uurimisobjektid minevikus ei ole samal viisil piiritletavad. Kui kõnelda traditsioonilistest ajalooteaduse valdkondadest, siis esmalt tuleb kindlasti nimetada laiemat kultuuri- ja raamatuajalugu, mis ei saa mööda vaadata uuritavate tekstide sisust ehk mõtteajaloolisest probleemistikust, ${ }^{31}$ aga ka sotsiaal- ja majandusajaloos on mär-

M. Laur, P. Piirimäe. (Quellen und Studien zur baltischen Geschichte, 23.) Böhlau, Köln, Weimar, Wien, 2014, 153-182; Kalmo, H. Iseseisvusdeklaratsioonid 1776-1918. - Methis: Studia humaniora Estonica, 2011, 6 (8), 143-161; Kalmo, H. Enesemääramise saatuslik tund. - Iseseisvusmanifest: Artikleid, dokumente ja mälestusi. Koost T. Tannberg, A. Pajur. Rahvusarhiiv, Tartu, 2014, 163-234; Kello, K., Siimets-Gross, H. Kohtuasjad in puncto libertatis: Isiku staatuse tuvastamise lähtekohad asehaldusaja Eestimaal. - Ajalooline Ajakiri, 2017, 2/3, 257-308; Siimets-Gross, H., Ristikivi, M., Kello, K. Favor libertatis: The ancient regula iuris as an argument for freedom in the courts of the late 18th century in the provinces Estland and Livland of the Russian Empire. „Ius commune graeco-romanum“: Essays in Honour of Prof. Dr. Laurent Waelkens. Ed. by M. Castelein et al. Peeters Publishers, Leuven, 2019, 209-223; Siimets-Gross, H. A letter from detention: The edition of letters of Livonian humanistic lawyer David Hilchen as an interdisciplinary challenge. - History of law and other humanities: Views of the legal world across the time. Ed. by V. Amorosi et al. Universidad Carlos III de Madrid, Madrid, 2019, 391-405.

${ }^{27} \mathrm{Nt}$ Karl Ernst von Baeri maja teadusloo uurimise keskus (juht Erki Tammiksaar); Teadusajaloo ja Teadusfilosoofia Eesti Ühendus (esimees Peeter Müürsepp); Tartu Ülikooli muuseum (Lea Leppik, Janet Laidla jt).

${ }^{28} \mathrm{Nt}$ Kalling, K., Tammiksaar, E. Descent versus extinction: the reception of Darwinism in Estonia. - The reception of Charles Darwin in Europe. Ed. by E. M. Engels, T. F. Glick. (The Reception of British and Irish authors in Europe.) Continuum Publishers, London, New York, 2008, 217-229; Kalling, K. Darwin Haeckeli varjus: Evolutsiooniõpetuse retseptsioonist Eestis. - Ajalooline Ajakiri, 2012, 3/4 (141/142), 287-308; Kalling, K. Application of eugenics in Estonia 1918-1940. Baltic eugenics: Bio-politics, race and nation in interwar Estonia, Latvia and Lithuania. Ed. by B. Felder, P. Weindling. Rodopi, Amsterdam, 2013, 49-82.

${ }^{29}$ Mitmed Tartu Ülikooli usuteaduskonna väitekirjad on pigem laia intellektuaalajaloolise kui kitsama usundiloolise fookusega, nt Friedenthal, M. Tallinna Linnaarhiivi Tractatus moralis de oculo. Tartu Ülikool, 2008; Rein, K. Arstiteadus rootsiaegses Tartu gümnaasiumis ja ülikoolis aastatel 1630 1656: Meditsiinialased disputatsioonid ja oratsioonid ning nende autorid. Tartu Ülikool, 2011; Lepajõe, M. Pastorid ja kirjakultuur: Kristliku humanismi variatsioonidest Eesti- ja Liivimaal XVII sajandi esimesel poolel. Tartu Ülikool, 2018; Friedenthal, T.-E. Võitlus ja väitlus teatri üle Eestija Liivimaal 18. sajandi lõpus ja 19. sajandi alguses. Tartu Ülikool, 2020. Vt ka teemanumber „Religiooni ja ateismi ajaloost Eestis“" (koost M. Friedenthal, A. Remmel. Ajalooline Ajakiri, 2012, 3/4, $141 / 142)$.

${ }^{30} \mathrm{Nt}$ Kaljundi, L., Kreem, T.-M. Ajalugu pildis - pilt ajaloos: Rahvuslik ja rahvusülene minevik eesti kunstis $=$ History in images - Image in history: National and transnational past in Estonian art. Eesti Kunstimuuseum, Kumu kunstimuuseum, Tallinn, 2018; Jõekalda, K. Monuments as a responsibility: Baltic German learned societies and the construction of cultural heritage around 1900. - Zeitschrift für Ostmitteleuropa-Forschung, 2019, 2, 189-222.

${ }^{31}$ Viimased tosin aastat pakuvad palju näiteid kultuuri-, religiooni-, kirjandus- ja mõtteajaloo põimumisest, nt käsitlused Liivimaa „konstrueerimisest“ 13. sajandil: Tamm, M. Inventing Livonia: Religious and geographical representations of the eastern Baltic region in early thirteenth century = Liivimaa leiutamine: Ida-Baltikumi religioosne ja geograafiline kujutamine 13. sajandi esimesel poolel. Doktoritöö. Tallinna Ülikool, Ajaloo Instituut, 2009; Kaljundi, L. Expanding communities: Henry of Livonia on the making of a Christian colony, early thirteenth century. - Imagined communities on the Baltic Rim, from the eleventh to fifteenth centuries. Ed. by W. Jezierski, L. Hermanson. 
gata kasvavat huvi nende valdkondadega seotud ideedeajalooliste küsimuste vastu. ${ }^{32}$

Neljanda faktorina, mis viimastel aastakümnetel on andnud tugeva tõuke Eesti mõtteloo laiemale teadvustamisele ja seeläbi ka teaduslikule uurimisele, on ajalooliste autorite tekstide taasavaldamine. Mastaapseimaks selliseks projektiks on kujunenud Hando Runneli eestvedamisel 1995. aastal Ilmamaa kirjastuses käivitatud „Eesti mõtteloo" sari, kus praeguseks on ilmunud juba 151 köidet. Sarja üks algatajaid ja suunaseadjaid Ülo Matjus on kirjutanud, et selle „mitte lihtsalt rahvusliku, vaid rahvuse ürituse“ eesmärk on „avaraimalt, sihikindlalt ja visalt [kaardistada] ühe väikese rahva mõtlemise ajalugu - eesti mõttelugu - avastamaks seda mitte ainult tänaseile, vaid säilitamaks ka tulevastele põlvedele". ${ }^{33} \mathrm{Ka}$ sarja ametlikus tutvustuses on Eesti mõttelugu piiritletud avaralt, viidates ,meie suurmeeste ja -naiste“ loomingule „filosoofia, kunstiteaduse, majanduse, poliitika, ajaloo ja muudel aladel“. ${ }^{44}$ Autorite ja tekstide valikul on seda laia valikukriteeriumit tõepoolest ka järgitud. „Eesti mõtte-

Amsterdam University Press, Amsterdam, 2016, 191-221. Piret Lotmani käsitlus Heinrich Stahli tegevusest ja vaadetest ortodoksse luterluse ideede kontekstis (Lotman, P. Heinrich Stahli elu ja looming. (Eesti Rahvusraamatukogu toimetised, 14. Raamat ja aeg, 3.) Eesti Rahvusraamatukogu, Tallinn, 2014) ja teised köited Rahvusraamatukogu sarjas „Raamat ja aeg“ (Ajalookirjutaja aeg = Aetas historicorum. Koost P. Lotman. Eesti Rahvusraamatukogu, Tallinn, 2008; Lugemise kunst = The art of reading. Eesti Rahvusraamatukogu, Tallinn, 2011; Konfessioon ja kirjakultuur $=$ Confession and the literary culture. Koost P. Lotman. Eesti Rahvusraamatukogu, Tallinn, 2016; Reformatsioon - tõlked ja tõlgendused $=$ Reformation - translations and interpretations. Koost P. Lotman . Eesti Rahvusraamatukogu, Tallinn, 2019), samuti Katre Kaju koostatud artiklikogumikud Rahvusarhiivi toimetiste sarjas (Kroonikast kantaadini: Muusade kunstid kesk- ja varauusaegsel Eesti- ja Liivimaal. Koost K. Kaju. Eesti Ajalooarhiiv, Tartu, 2013; Balti kirjasõna ja kultuurielu valgustusajastu peeglis. Koost K. Kaju. Eesti Ajalooarhiiv, Tartu, 2014; Kroonikast epitaafini: Eesti- ja Liivimaa varauusaegsest haridus- ja kultuurielust. Koost K. Kaju. Rahvusarhiiv, Tartu, 2017), samuti Jürgen Beyeri raamatuajaloolised uurimused (nt Beyer, J. Pietist tracts in Swedish, printed at Reval/Tallinn in the early eighteenth century: Background and bibliographical career. - Ajalooline Ajakiri, 2014, 1 (147), 115-135).

${ }^{32} \mathrm{Nt}$ Marten Seppel on viimastel aastatel käsitlenud lisaks sotsiaalajaloolistele teemadele ka majandusliku ja ühiskondliku mõtte ajalugu (Seppel, M. Cameralist population policy and the problem of serfdom, 1680-1720. - Cameralism in practice: State administration and economy in early modern Europe. Ed. by M. Seppel, K. Tribe. Boydell \& Brewer, Woodbridge, 2017, 91-110; Seppel, M. The semiotics of serfdom: How serfdom was perceived in the Swedish conglomerate state, 1561-1806. - Scandinavian Journal of History, 2020, 45, 1, 48-70) ning juhib praegu rahvusvahelist teadusprojekti, mille keskmes on poliitökonoomilised ideed varauusajal (PRG318 „Ümberkorraldustele aluste loomine: Muutuste poliitilised ja majanduslikud argumendid Läänemere ruumis varauusajal“ 2019-2023). Sotsiaalajalugu, mõtteajalugu ja kirjandusajalugu on ühendatud Ulrike Plathi teadustöös (Plath, U. Esten und Deutsche in den baltischen Provinzen Russlands: Fremdheitskonstruktionen, Lebenswelten, Kolonialphantasien 1750-1850. Harrassowitz, Wiesbaden, 2011) ning ka tema juhitav vastne teadusprojekt on tugeva ühiskondliku mõtte ajaloo suunitlusega (PRG908 „Eesti keskkonnaliikumine 20. sajandil: ideoloogia, diskursid, praktikad“ (2020-2024), Ulrike Plath, Tallinna Ülikool, humanitaarteaduste instituut, ajaloo, arheoloogia ja kunstiajaloo keskus).

${ }^{33}$ Matjus, Ü. Eesti mõttelugu 1995-2004: Kataloog. Ilmamaa, Tartu, 2004, v. Põhjalikum ülevaade sarja eesmärkidest: Matjus, Ü. Uitamisi Eesti mõtteloos. - Rahvusvahelised rahvusteadused: Artiklikogumik rahvusülikooli 95. juubeliks. Toim T. Hennoste. Tartu Ülikooli Kirjastus, Tartu, 2014, $191-$ 205.

${ }^{34} \mathrm{https}$ ://www.ilmamaa.ee/mottelugu (20.06.2020). 
lugu“ taaselustab Eesti mõttepärandi võtmetekste 17. sajandist 21. sajandini, hõlmates valdkondlikult nii ühiskondlik-poliitilist mõtet kui ka humanitaar- ja reaalteaduste ajalugu. Tähele tuleb panna ka seda, et eesti mõttevara all ei ole mõistetud vaid praeguse Eesti territooriumil loodud eestikeelset loomingut, vaid sarjas on välja antud ka eesti päritolu teadlaste võõrsil ja võõrkeeles loodud tekstide tõlkeid. Veelgi enam, „meie suurmeeste“ hulka on loetud ka Eestis elanud või siit pärit saksa soost kirjamehed (Hermann von Keyserling, Georg Julius von Schultz-Bertram, Jakob von Uexküll) ja keiserliku Tartu ülikooliga seotud vene teadlased (Vladimir Tšiž). ${ }^{35}$

Lisaks nii algupärastele kui taasavaldatud trükistele on uurijatel võimalik toetuda digitaalsetele andmebaasidele, nagu Tartu Ülikooli raamatukogus koostatud Eesti vanema kirjanduse digitaalne tekstikorpus Eeva, Eesti Rahvusraamatukogu digitaalarhiiv Digar ja Eesti Kirjandusmuuseumi failirepositoorium Kivike. Need mitte ainult ei tee teadlaste tööd praktilises mõttes lihtsamaks, vaid masinloetavate tekstide lisandumine võimaldaks tulevikus uurida mõistete ja fraaside kasutamist ka kvantitatiivsete meetoditega ning avastada uusi seoseid mõistete digitaalse analüüsi teel.

\section{MÕTTEAJALOO IDENTITEEDIST}

Eelneva ülevaate põhjal võis tekkida küsimus, et kui peaaegu kõik humanitaaria distsipliinid tegelevad otsapidi ka ideede uurimisega, siis kas intellektuaalajalool või mõtteajalool on üldse mingi iseseisev identiteet - kas tal on olemas kehand või niriseb ta haarates sõrmede vahelt läbi? Intellektuaalajaloolased on oma valdkonna olemuse ja eripära üle aastakümneid piike ristanud ${ }^{36}$ ning väljendatud on ka arvamust, et tegu pole mitte niivõrd omaette distsipliiniga, vaid interdistsiplinaarsete meetodite kogumiga või randevuu-distsipliiniga ehk distsipliinide ristteega, mille ühendavaks mõõtmeks on ajalooline seletusviis. ${ }^{37}$ Tõepoolest, vaatenurkade ja

${ }^{35}$ Vt ka Matjus, Ü. Omad ja võõrad „Eesti mõtteloo“ taustal. - Tartu Ülikooli ajaloo küsimusi, 2016, 44, 37-48; Piirimäe, P. Eesti mõttelugu ajas ja ruumis. - Sirp, 23.02.2018.

${ }^{36}$ Mõtteajaloolased on regulaarselt tegelenud valdkondliku sisekaemusega, mida on tinginud kas kriisitunnetus või hoopis vastupidine tunne liigsest enesega rahulolust. Nt Modern European intellectual history: Reappraisals and new perspectives. Ed. by D. LaCapra, S. L. Kaplan. Cornell University Press, Ithaca NY, 1982; LaCapra, D. Rethinking intellectual history: Texts, contexts, languages. Cornell University Press, Ithaca NY, 1983; Richter, M. Begriffsgeschichte and the history of ideas. - Journal of the History of Ideas, 1987, 48, 247-263; Kelley, D. R. What is happening to the history of ideas? - Journal of the History of Ideas, 1990, 51, 3-25; Pocock, G. A. Political thought and history: Essays on theory and method. Cambridge University Press, Cambridge, 2009; Skinner, Q. Visions of politics I: Regarding method. Cambridge University Press, Cambridge, 2002; Rethinking modern European intellectual history. Ed. by D. M. McMahon, S. Moyn. Oxford University Press, Oxford, 2014; Whatmore, R. What is intellectual history? Polity Press, Cambridge, 2016; Collini, S. The identity of intellectual history. - A companion to intellectual history. Ed. by R. Whatmore, B. Young. Wiley Blackwell, Chichester, 2016, 7-18. Vt ka Bevir, M. The logic of the history of ideas. Cambridge University Press, Cambridge 1999; Kelley, D. R. The descent of ideas: The history of intellectual history. Ashgate, Aldershot, 2002.

${ }^{37}$ Breckman, W. Intellectual history and the interdisciplinary ideal. - Rethinking modern European intellectual history, 275-293, 286. 
uurimisobjektide mitmekesisuse tõttu ei ole võimalik rääkida rangepiirilisest distsipliinist, kuid eristatav on siiski teatav tuum, mis neid käsitlusi liidab. Valdkonna ühisnimetajaks on inimese intellektuaalne tegevus ja selle tulemid ajaloos. Kõige üldisemalt öeldes uurib mõtteajalugu inimmõtet ajaloos ehk siis mitte sotsiaalset reaalsust, vaid seda, kuidas inimene seda reaalsust on tõlgendanud ja esitanud (või representeerinud). Intellektuaalajaloo saab seega positsioneerida laiale spektrile filosoofiaajaloo ja kultuuriajaloo vahel. Ta jagab mõlemaga osaliselt nii uurimisobjekte kui ka metoodikat, ent samas neist mõlemast siiski piisavalt eristudes. Kui filosoof keskendub ajaloolise mõtleja argumendi sisulisele loogikale, tõmmates ajaloolise teksti tänapäevase filosoofia liistule, ${ }^{38}$ siis mõtteajaloolane vaatleb ajaloolist mõtlejat tema omaaegses kontekstis ning hoidub tema mõtete tõeväärtuse hindamisest ja edasiarendamisest. Kultuuriajalooline vaatenurk võtab aga vaatluse alla kõikvõimalikud representatsioonid, mis võivad väljenduda nii tekstides kui piltides - või olla hoopis artikuleerimata „mentaliteet“ või „maailmavaade“, mis kajastub kultuurilistes praktikates. Mõtteajalugu näib keskenduvat mõnevõrra kitsamalt süstemaatilisemat ja abstraktsemat laadi ideedele inimese, ühiskonna ja ümbritseva maailma kohta, mis eeldab, et need ideed on üldjuhul ka tekstilisel kujul kirja pandud või esitatud. Kui defineerida kultuuriajalugu laiemas võtmes kui esituste ja tähenduste ajalugu, ${ }^{39}$ siis on igasugune intellektuaalajalugu ühtlasi ka kultuuriajalugu, kuivõrd ta uurib mitte reaaliaid või tegutsemist, vaid nende esitust ja neile tähenduste andmist. Aga mitte igasugune kultuuriajalugu ei ole intellektuaalajalugu.

Vaidlused mõtteajaloo distsiplinaarse olemuse üle võibki lihtsustavalt kokku võtta kui distsipliini sikutamist ühe või teise otspunkti poole - lähemale ideelistele abstraktsioonidele või ajaloolisele praktikale. Tänapäevase intellektuaalajaloo üks peamisi eelkäijaid oli 1930. aastatel Johns Hopkinsi ülikooli filosoofiaprofessori Arthur Lovejoy loodud ideedeajaloo koolkond, mis käsitles ideid kui universaalseid ja ajatuid ühikuid, mida suured mõtlejad inimkonna igavikulistele küsimustele vastust otsides taaskasutavad ja uuesti kombineerivad. ${ }^{40}$ Sellele vastukaaluks kujunes 1970. aastatel Cambridge'i ülikooli teadlaste John Pococki, John Dunni ja Quentin Skinneri eestvedamisel nn kontekstuaalne meetod, mis rõhutas, et teksti adekvaatseks tõlgendamiseks peab uurija vältima oma ajastu küsimuseasetusi ja kontseptsioone ning mõistma autori enda kavatsust, mis omakorda tuleneb autori kaasaegsest ajaloolisest kontekstist. Cambridge'i koolkonna manifestiks on peetud Skinneri 1969. aasta artiklit „Meaning and understanding in the history of ideas", kus ta L. Wittengensteini ja J. L. Austini keelefilosoofiale tuginedes käsitleb tekste kui tegusid, mistõttu teksti tähenduse avamiseks peame rekonstrueerima uuritava ajastu praktilise konteksti, aga ka debatid, millega autor suhestub, keelelised ressursid, mida kasutab, ja mõisted, mil-

\footnotetext{
${ }^{38}$ Siinkohal tuleb täpsustada, et filosoofia ajalugu saab mõistagi uurida ka intellektuaalajaloolisel viisil, mida Eestis on ka tehtud, vt nt: Tagasi mõteldes: Töid filosoofia ajaloost Eestis.

${ }^{39}$ Vt Tamm, M. Kultuuriajalugu. - Kuidas uurida kultuuri? Kultuuriteaduste metodoloogia. Koost ja toim M. Tamm. (Gigantum Humeris.) Tallinna Ülikooli Kirjastus, Tallinn, 2016, 137-167.

${ }^{40}$ Sellesse koolkonda võib lugeda sellised ideedeajaloo suurkujud nagu Isaiah Berlin ja George Sabine.
} 
lega manipuleerib. ${ }^{41}$ Ligikaudu samal perioodil kujunes Reinhart Kosellecki ja Werner Conze juhtimisel Saksamaal välja nn mõisteajaloo (Begriffsgeschichte) koolkond, mis seadis eesmärgiks ühiskondlik-poliitiliste põhiterminite tähendusväljade muutumise uurimise, suhtudes samamoodi kriitiliselt varasemasse ideedeajaloo traditsiooni. Kontekstuaalse suunaga on paljuski kongeniaalne ka Michel Foucault' nn arheoloogiline meetod, mis keskendub suurte mõtlejate ideede asemel pigem keelele ja (võimu)diskursustele. Võib öelda, et Cambridge'i koolkonna ideedest lähtuv kontekstuaalne uurimistraditsioon on viimasel poolsajandil paljudes maades kõige tugevamalt etableerunud ning suutnud toime tulla mitmest suunast saadetud kriitikanooltega. Sotsiaalajaloo tõusulaines hakati seda 1970. ja 1980. aastatel süüdistama liigses elitaarsuses ning sellest tulenevas liiga väheses seotuses sotsiaalse praktika ehk ,tegeliku ajalooga““ ${ }^{42}$ Alternatiivsete uurimistraditsioonidena kujunesid välja laiemate ühiskonnakihtide vaateid uuriv (mikroajalooline) mentaliteediajalugu ja sotsiokultuuriline intellektuaalajalugu, mis keskendus raamatute levikule ja lugemispraktikatele. ${ }^{43}$ Samas on kontekstuaalset käsitlusviisi viimastel aastatel kritiseeritud rohkem isegi vastupidisest suunast, näiteks Peter Gordon on Skinneri metodoloogiale ette heitnud filosoofilise relevantsuse puudumist, mis tema hinnangul tuleneb teksti tõlgendamisvõimaluste sulgemisest selle tekkeajastu „hermeetilise“ kontekstiga. ${ }^{44}$

\section{DISTSIPLIINI NIMETUSEST EESTIS}

Nende rahvusvaheliste arengujoonte ja distsipliini eneseanalüüsi taustal on võimalik hinnata mõtteajaloo viimaste aastakümnete suundumusi Eestis. Esmalt lühidalt distsipliini omanimest. Ajalooliste ideede uurimise õhukesest kodumaisest traditsioonist tulenevalt ei ole eesti keeles välja kujunenud üheselt arusaadavat ja kasutatavat mõistestikku selle distsipliini tähistamiseks, vaid käibel on mitu paralleelset terminit, millel on oma tähendusnüansid ja konnotatsioonid, mida tuleks arvesse võtta. Eespool olen kasutanud samatähenduslikult termineid mõttelugu/mõtteajalugu ja intellektuaalajalugu, mille puhul eelistus sõltub sellest, kas peetakse paremaks oma-

${ }^{41}$ Skinner, Q. Meaning and understanding in the history of ideas. - History and Theory, 1969, 8, 1, 3-53. Vt ka Piirimäe, E. Keeleline pööre. - Humanitaarteaduste metodoloogia: Uusi väljavaateid. Koost ja toim M. Tamm. (Gigantum Humeris.) Tallinna Ülikooli Kirjastus, Tallinn, 2011, 33-58.

42 Darnton, R. Intellectual and cultural history. - The past before us: Contemporary historical writing in the United States. Ed. by M. Kammen. Cornell University Press, Ithaca, NY, 1980, 327-351. Hiljuti ka: Moyn, S. Imaginary intellectual history. - Rethinking modern European intellectual history, 112-130. Kaitseks elitaarsuse kriitika vastu on: Brett, A. What is intellectual history now? - What is history now? Ed. by D. Cannadine. Palgrave MacMillan, Houndmills, 2002, 113-131.

${ }^{43}$ Mõni esinduslikum näide: Ginzburg, G. Il formaggio e i vermi: Il cosmo di un mugnaio del ' 500 . Einaudi, Torino, 1976 (ee: Juust ja vaglad. Varrak, Tallinn, 2000, tlk V. Atkin); Darnton, R. The forbidden best-sellers of pre-revolutionary France. Norton, New York, 1995; Darnton, R. The great cat massacre and other episodes in French cultural history. Vintage Books, New York, 1984. Martin, J.-H. Le livre français sous l'Ancien Régime. Promodis, Paris, 1987.

${ }^{44}$ Gordon, P. E. Contextualism and criticism in the history of ideas. - Rethinking modern European intellectual history, 32-55. 
keelset sõna või otsetõlget inglise keeles domineerivast nimetusest. ${ }^{45}$ „Mõtteloo“ termini kinnistumisel on pearolli mänginud „Eesti mõtteloo“ sari, mis on andnud nime ka Tartu Ülikoolis 2018. aastal asutatud mõtteloo professuurile. ${ }^{46}$ „Mõttelugu“ on tõepoolest kohane sõna interdistsiplinaarse mõttepärandi tähistamiseks selle avaras geograafilises ja interdistsiplinaarses kontekstis. Terminina on „,mõte“ ju paljudes teadusvaldkondades juba keeleliselt kinnistunud, näiteks räägitakse „seltskondlikust“" ehk ühiskondlikust mõttest eesti keeles juba üle saja aasta. ${ }^{47}$ Analoogselt kõneldakse filosoofilise mõtte, ${ }^{48}$ kunstimõtte, ${ }^{49}$ arhitektuurimõtte, ${ }^{50}$ teadusmõtte $^{51}$ jne $^{52}$ ajaloost, mis tervikuna moodustavad laialt piiritletud mõtteloo ainese. $^{53}$

Tekib siiski küsimus, kas „,mõttelugu“ sobib korraga tähistama nii uurimisobjekti kui ka seda uurivat distsipliini või peaksid terminid eristuma. Mõnel puhul nimetused ju kattuvad, näiteks tähistab ,ajalugu“ nii minevikus sündinud asju kui ka nende uurimist. Enamikus distsipliinides on võimalik neid siiski eritleda, näiteks uurib kultuuriajaloolane kultuurilugu, usundiajaloolane usundilugu ja kirjandusajaloolane kirjanduslugu, isegi kui rahvapärasemalt saab kõnelda ka kultuuriloolasest või kirjandusloolasest. ${ }^{54}$ Seda terminoloogilist traditsiooni järgides näib mõistlik kõnelda „mõtteajaloost“" kui mõtteloo uurimise distsipliinist. Sünonüümina on kasutatav ka „intellektuaalajalugu“", mis on sobiv termin viitamaks samale distsipliinile rahvusvahelises teaduses, ent kõlab eesti keeles veel mõnevõrra kohmakalt ja harjumatult. ${ }^{55}$

Lisaks on eesti keeles alternatiivsete terminitena kasutatud ka „,ideedeajalugu“/,ideeajalugu“ ja „vaimulugu“/,vaimuajalugu“ ${ }^{56}$ Kui mõtteajalugu ja intellektuaalajalugu on tähendusvälja poolest teineteisest sisuliselt eristamatud, siis

\footnotetext{
45 Tasub märkida, et naaberrahvastel soomlastel on omakeelne nimetus aatehistoria ja rootslastel pooleldi omakeelne idé- och lärdomshistoria.

${ }^{46}$ Professuuri asutamise ja nimepaneku tausta kohta vt: Matjus, Ü. Uitamisi Eesti mõtteloos.

${ }^{47}$ Esialgne termin oli „seltskondlik mõte“: Ruubel, P. Intelligentlikust liikumisest meil. - Vaba Sõna, 1914, 1, 25. Hans Kruusil juba ,ühiskondlik mõte“: Kruus, H. Oleviku asutamine [1932]. - Kruus, H. Eesti küsimus. Koost T. Karjahärm, H. Runnel. (Eesti mõttelugu, 62.) Ilmamaa, Tartu, 2005. 171

${ }^{48}$ Filosoofia akadeemilise suletuse paines [Eesti Humanitaarinstituudi filosoofide vestlusring]. - Sirp, 07.03.2003.

${ }^{49}$ Varblane, R. Feministlikul mõttel on koht meie kunstiajalugudes. - Sirp, 05.11.2004.

${ }^{50}$ Valk, V. Lihtne ja ühtlasi rikkalik: Arhitektuurimõte Jaapanist. - Eesti Päevaleht, 12.06.2014.

${ }^{51}$ Talts, M. Teadusmõtte ja teaduse mineviku lood. - Sirp, 30.09.2011.

${ }^{52}$ Samuti leiab näiteid regionaalsetest mõttelugudest, nt: Ida mõtteloo leksikon: Lõuna-, Ida- ja SiseAasia. Toim L. Mäll, M. Läänemets, T. Toome. Tartu Ülikool, Tartu, 2006.

53 Ülo Matjus on kirjutanud mõtteloost kui „,mõtlemise ajaloost“, mis mahutab nii teaduslikku kui ka mitteteaduslikku mõtlemist minevikust kaasajani: Matjus, Ü. Uitamisi Eesti mõtteloos.

${ }^{54}$ Sellised on näiteks ka online-entsüklopeedia jaotused: http://entsyklopeedia.ee/kategooria/eesti_kul tuuriloolased; http://entsyklopeedia.ee/kategooria/eesti_kirjandusloolased (01.07.2020).

${ }^{55}$ Eesti keelde ongi termin jõudnud tõlgete kaudu (nt Latour, B. Me pole kunagi olnud modernsed: Essee sümmeetrilisest antropoloogiast. Tlk A. Saar. (Bibliotheca controversiarum.) Tallinna Ülikooli Kirjastus, Tallinn, 2014, 41; https://www.ut.ee/et/uudised/klassikalised-filoloogid-loovad-euroopaintellektuaalajaloo-digitaalset-raamistikku), ent on leidnud kasutust ka ametikohtade nimetustes (Tartu Ülikooli raamatukogu intellektuaalajaloo vanemteadur).

${ }^{56} \mathrm{Nt}$ Hyrkkänen, M. Ideeajaloo mõte.
} 
ideedeajalugu ja vaimuajalugu kannavad mõlemad endaga konkreetsete varasemate teadustraditsioonide ballasti. ${ }^{57}$ Kuna ideedeajaloo mõiste assotsieerub Lovejoy arendatud metodoloogiaga, on see valdkonna üldnimetuseks pisut vähem sobilik, ent on omal kohal just siis, kui kontekstuaalse lähiuurimise või autorikeskse analüüsi asemel võetakse ette mõne konkreetse mõiste või juhtmõttega seotud ideede klastri arengu uurimine pikema perioodi vältel. ${ }^{58}$ Ideedeajalugu ei pea ju tingimata tähendama kontekstist väljarebitud ,ühik-ideede“ üleajalooliste liikumistrajektooride tuvastamist, vaid võib lähtuda ka David Armitage'i lansseeritud ,ajalugu ideedes“ (history in ideas) kontseptsioonist, mis paneb ette uurida ideede muutumist küll pikas kestuses, aga „seeriaviisiliselt kontekstualiseerituna“ ehk ankurdatuna konkreetsetes ajaloolistes võtmesituatsioonides..$^{59}$

Termini „,vaimuajalugu“ näol on tegu tõlkega saksakeelsest Geistesgeschichte'st ning see kannab endas tolle distsipliini filosoofilist ja metodoloogilist aluspõhja, millest nüüdisaegne intellektuaalajalugu on õigustatult loobunud. Ehkki eesti keeleruumis ei pruugita seda pärandit alati teadvustada ja terminit kasutatakse seetõttu neutraalselt ${ }^{60}$ seostub vaimuajalugu Teise maailmasõja eelsel Saksamaal domineerinud taotlusega uurida ideid mitte üksiku või abstraktsena, vaid orgaanilises terviklikkuses või maailmavaatelises totaalsuses kui ajastu (ja rahvuse) vaimu peegeldusi. ${ }^{61}$ Just see pärand on põhjuseks, miks ka saksa akadeemilises traditsioonis on viimastel aastakümnetel terminit Geistesgeschichte järjest vähem kasutatud ning parema puudumisel naastud 20. sajandi algul domineerinud termini Ideengeschichte juurde. Paul Nolte on sealjuures kutsunud üles lähendama saksa ideedeajalugu angloameerika juurtega intellectual history traditsioonile. ${ }^{62}$

${ }^{57}$ Mart Kivimäe on kasutanud termineid „mõttelugu“, „,intellektuaalajalugu“ ja ,,vaimuajalugu“, neid rangelt eritlemata: Kivimäe, M. Intellektuaalajaloo orienteerumisrajal Brandes, Jaspers, Lukács Kierkegaardist Nietzscheni. - Sirp, 04.06.2010. Vt ka tema varasemat arutlust idee-, vaimu- ja intellektuaalajaloo piiritlemise kohta: Kivimäe, M. Georg G. Iggers ajalooteaduse ajaloolasena. Tuna 2001, 1, 11-14.

${ }^{58}$ Eestis näiteks hiljuti kaitstud doktoriväitekiri: Rajavee, H. Moodsa kunstnik-geeniuse idee sünd ja kujunemine Prantsuse ja Briti traditsiooni põhjal 17.-18. sajandil ning selle refleksioonid 20. sajandil. Tartu Ülikooli Kirjastus, Tartu, 2019. Ka siinse artikli autor on alates 2007. aastast lugenud Tartu Ülikoolis ainekursust „Euroopa ideede ajalugu“, mille ülesehitus lähtub ühiskonna- ja moraalifilosoofia põhimõistetest.

${ }^{59}$ Armitage, D. Civil wars: A history in ideas. Alfred A. Knopp, New York, 2017, 20-21. Seda meetodit pü̈̈ab edasi arendada Eestis 2020. aastal alanud teadusprojekt „Rahvaste enesemääramine ajaloolises perspektiivis“ (PRG942, juht Eva Piirimäe), vt ka: Piirimäe, E. Enesemääramise idee ajalugu. - Sirp, 23.02.2018.

${ }^{60}$ Näiteks märksõnana raamatukogude kataloogides Ester (https://www.ester.ee/) ja Digar (https://www.digar.ee/arhiiv/et).

${ }^{61}$ Goering, D.T. Einleitung: Ideen- und Geistesgeschichte in Deutschland - eine Standortbestimmung. - Ideengeschichte heute: Traditionen und Perspektiven. Hrsg. v. D. T. Goering. Transcript Verlag, Bielefeld, 2017, 10, 16, 33. Selle idee historistlike juurte kohta vt: Dilthey, W. Vaimne maailm: Sissejuhatuse elufilosoofiasse. Koost ja tlk A. Tool. (Avatud Eesti raamat.) Ilmamaa, Tartu, 2018, 316 319; Tool, A. Wilhelm Dilthey akadeemiline elufilosoofia. - Dilthey, W. Vaimne maailm, 358-360.

${ }^{62} \mathrm{Nt}$ Nolte, P. Sozialgeschichte und Ideengeschichte: Plädoyer für eine deutsche „Intellectual History“. - Nolte, P. Transatlantische Ambivalenzen: Studien zur Sozial- und Ideengeschichte des 18. bis 20. Jahrhunderts. De Gruyter, Berlin, 2014, 391-414. 


\section{MÕTTEAJALOO MEETODID, ŽANRID JA UURIMISPERSPEKTIIVID EESTIS}

Selle terminoloogilise arutelu pinnalt saab viimaste kümnendite uurimistöös kasutatud meetodite alusel kõnelda spektrist, mille ühes servas on mõtteajalugu selle sõna rangemas tähenduses kui kontekstuaalne intellektuaalajalugu ning teises servas vaimuajalugu/ideedeajalugu. Esimese käsitlusviisi eesmärk on tõlgendada autori kavatsust teksti kirjutamisel, milleks on vajalik pragmaatilisest ja intellektuaalsest kontekstist tulenevate kõnesituatsioonide rekonstrueerimine. ${ }^{63}$ Spektri teise serva jäävad vaimuajalugu, mis uurib ,ajastu vaimu“ tervikuna, toetumata konkreetsete autorite või tekstide süvauurimisele, ning hegelliku laadi ideeajalugu, mis lahutab ideed nende kandjatest, jättes äärmuslikematel juhtudel mulje, et üleajaloolised ja abstraktsed ideed „rändavad läbi ajastute omaenese jõul, üksnes juhuslikult ja ajutiselt peatudes konkreetsete mõtlejate peades". 64

Pole üllatav, et mujal maailmas intellektuaalajaloo uurimise keskustes teaduskraadi omandanud ajaloolaste põlvkond eelistab kontekstuaalset meetodit, ent selle järjekindlam rakendamine Eesti mõtteloo uurimisele on alles algusjärgus. Nende uurimishuvi teravik on pigem olnud suunatud laiemale Euroopa või maailma mõtteloole, mis on selgitatav asjaoluga, et Cambridge'i traditsioon ongi peaasjalikult olnud huvitatud kõige süsteemsematest, uuenduslikumatest ja mõjukamatest mõtlejatest, keda on uusi relevantseid kontekste välja tuues järjepanu ümber tõlgendatud. ${ }^{65}$ Koolkonda on küll seostatud ka teisejärgulisemate autorite uurimisega, ent need on pakkunud huvi eeskätt kui kontekst, mis aitab selgitada võtmetähtsusega autorite kõnetegusid. Eesti mõtteloost on maailmaajalooliselt mõjukaid mõtlejaid, kelle ideede rekonstrueerimine ja kontekstualiseerimine oleks filosoofilises plaanis samavõrd atraktiivne ja ambitsioonikas, raskem leida. ${ }^{66} \mathrm{Nii}$ on Liisi Keedus uurinud Hannah Arendti ja Leo Straussi ideede intellektuaalseid juuri Weimari-Saksamaal ja USA poliitikateaduse kujunemist ${ }^{67}$ ning Eva Piirimäe Euroopa valgustuse

${ }^{63}$ Quentin Skinner tõlgendas J. L. Austini keelefilosoofiale tuginedes väiteid kui „kõnetegusid“, mistõttu intellektuaalajaloo eesmärk on kindlaks teha, mida autor oma tekstidega „tegi”. Skinner, Q. Meaning and understanding in the history of ideas. Vt Hamilton-Bleakley, H. Linguistic philosophy and The Foundations. - Rethinking the foundations of modern political thought. Ed. by A. Brett, J. Tully, H. Hamilton-Bleakley. Cambridge University Press, Cambridge, 2006, 20-36. Eksemplaarne näide Skinneri teadustööst on nüüd ka eesti keelde tõlgitud: Skinner, Q. Uusaegse poliitilise mõtte alused. Tlk T. Pakk. (Avatud Eesti raamat.) EKSA, Tallinn, 2020.

${ }^{64}$ Tsitaat Stefan Collinilt: Collini, S. What is intellectual history? - History Today, 1985, 35, 10, 47.

${ }^{65}$ Pilk koolkonnaga seotud väljaannetele (ajakirjad History of Political Thought, Intellectual History Review, Modern Intellectual History jt või raamatusari ,Ideas in context“) näitavad, et jätkuvalt on peatähelepanu all nn suured mõtlejad (Machiavelli, Hobbes, Locke, Hume, Smith, Hegel, Marx, Arendt jt), kes kuulusid juba varasema ideedeajaloo traditsiooni kaanonisse, ent nende kõrval on koha leidnud ka vähem tuntud autorid. Vt ka Charette, D., Skjönsberg, M. State of the field: The history of political thought. - History: The Journal of the Historical Association, 26.06.2020, 1-14. https://doi.org/10.1111/1468-229X.13013 (20.06.2020).

${ }^{66}$ Annabel Brett on põhjendanud, miks just sellised autorid väärivadki suuremat tähelepanu: Brett, A. What is intellectual history now?

${ }^{67}$ Keedus, L. The crisis of German historicism: The early political thought of Hannah Arendt and Leo Strauss. Cambridge University Press, Cambridge, 2015; Keedus, L. The poesis of a disciplinary 
moraali- ja poliitikafilosoofiat, eriti J. G. Herderi loomingut. ${ }^{68}$ Siiski ei tähenda see, et kontekstuaalne meetod ei oleks Eesti mõtteloole rakendatav, sest selles meetodis ei ole midagi, mis nõuaks uuritavalt autorilt mingi lati ületamist filosoofilisuse, abstraktsuse, süsteemsuse või mõjukuse osas. Pealegi pakub suurte mõtlejate ideede retseptsiooni uurimine ühe produktiivse vaatlusviisi, mida seni pole Eesti mõtteloo uurimisel piisavalt kasutatud. Näiteks on Eva Piirimäe arutlenud võimaluste üle, kuidas eesti rahvusluse ideelist arengut saaks täpsemini paigutada avaramale rahvusvahelisele teoreetilisele ja ajaloolisele taustale ${ }^{69} \mathrm{Ka}$ siinse artikli autor on kirjutanud varasema Eesti ala mõtteloo uurimisperspektiividest seni vähem tähelepanu leidnud tekstide najal, nagu näiteks akadeemilised disputatsioonid, mida viimastel aastatel on filosoofiliste ja teaduslike ideede leviku ja kohandamise vaatepunktist juba viljakalt uuritud. ${ }^{70}$ Lisaks on võimalik ühiskondliku mõtte ajalugu uurida ka

metamorphosis: Rhetoric and ambition in American political science after World War II. - Trames: Journal of the Humanities and Social Sciences, 2018, 22, 1, 3-23. Keedus, L. The new world of Karl Barth: Rethinking the philosophical and political legacies of a theologian. - The European Legacy, 2019, 25, 2, 167-185. Keedus juhib praegu Tallinna Ülikoolis Euroopa Teadusfondi projekti TAU17149 „Aeg ja kriis: Anti-historism maailmasõdade vahelisel perioodil ja selle mõjud Euroopa mõtteloos“"(2018-2023).

${ }^{68}$ Piirimäe, E. Jean-Jacques Rousseau „Teine arutlus“ (1755) ajaloolises kontekstis: sissejuhatus. Akadeemia, 2008, 12, 2765-2785; Piirimäe, E. Dying for the fatherland: Thomas Abbt's theory of aesthetic patriotism. - History of European Ideas, 2009, 35, 2, 194-208; Piirimäe, E. Philosophy, sociability and modern patriotism: Young Herder between Rousseau and Abbt. - History of European Ideas, 2015, 41, 5, 640-661; Piirimäe, E. Sociability, nationalism, and cosmopolitanism in Herder's early philosophy of history. - History of Political Thought, 2015, 36, 3, 521-559; Piirimäe, E. State-machines, commerce and the progress of humanität in Europe: Herder's response to Kant in ideas for the philosophy of history of mankind. - Commerce and peace in the Enlightenment. Ed. by R. Whatmore, I. Nakhimovsky, B. Kapossy. Cambridge University Press, Cambridge, 2017, 155-191; Piirimäe, E. Johann Gottfried Herder: Mõtteid inimkonna ajaloo filosoofiast: Saateks. - Herder, J. G. Mõtteid inimkonna ajaloo filosoofiast. Tlk K. Räni. (Avatud Eesti raamat.) Ilmamaa, Tartu, 2019, 955-984. Eva Piirimäe juhib praegu Tartu Ülikoolis ETAg-i teadusprojekti „Rahvaste enesemääramine ajaloolises perspektiivis“ (2020-2024).

${ }^{69}$ Piirimäe, E. Teoreetilisi perspektiive 19. sajandi eesti rahvuslusele. - Vene impeerium ja Baltikum: Venestus, rahvuslus ja moderniseerimine 19. sajandi teisel poolel ja 20. sajandi alguses. Toim T. Tannberg, B. Woodworth. (Eesti Ajalooarhiivi toimetised, 16 (23).). Eesti Ajalooarhiiv, Tartu, 2009, 167-191. Üks näide rakendusest: Piirimäe, E. Humanität versus nationalism as the moral foundation of the Russian Empire: Jegór von Sivers' Herderian cosmopolitanism. - Ajalooline Ajakiri, 2012, 1/2 (139/140), 79-113.

${ }^{70}$ Piirimäe, P. Early modern academic writings and intellectual history: Methods and perspectives of research. - Ajalooline Ajakiri, 2010, 3/4 (133/134), 247-262. Mõni näide sedalaadi uurimustest: Friedenthal, M. Senses and perception in seventeenth-century Academia Gustaviana and GustavoCarolina. - Ajalooline Ajakiri, 2010, 3/4 (133/134), 323-346; Friedenthal, M. Etümoloogia stiihiad. - Lugemise kunst, 272-285; Friedenthal, M. Ramism ja metafüüsika Academia Gustavianas. Raamat ja aeg, 98-117; Friedenthal, M. Nominal definition in the seventeenth-century university disputations of the German cultural space. - History of Universities, 29. Oxford University Press, Oxford, 2016, 65-87; Friedenthal, M. Ramism, metaphysics and pneumatology in the Swedish universities of the first half of the 17th century. - Early modern disputations and dissertations in an interdisciplinary and European context (ilmumas); Tering, A. Skorbuuditeema Baltimaade arstide dissertatsioonides varasel uusajal. - Ajalooline Ajakiri, 2013, 4 (146), 447-464; Tering, A. Uute füsioloogiaideede retseptsioonist Baltimaade meedikute väitekirjades 17. sajandi viimasel veerandil. Kroonikast epitaafini, 239-270. 
tekstide põhjal, millel puudub igasugune taotlus panustada teoreetilisse diskussiooni, vaid mis on suunatud mingite poliitiliste praktikate, institutsioonide või tegude põhjendamisele, õigustamisele või kritiseerimisele. ${ }^{71}$ Siinkirjutaja on sedalaadi legitimatsioonipraktikaid ja -retoorikaid uurinud nii Euroopas laiemalt ${ }^{72}$ kui ka Balti provintside ja Eesti näitel. ${ }^{73}$

Tulles vaimuajaloolise lähenemisviisi juurde, siis seda on kõige järjekindlamalt viljelenud Ilmar Vene oma Euroopa mõttelugu käsitlevates teostes, kus räägitakse mitte niivõrd konkreetsete autorite seisukohtadest, vaid „õhtumaise vaimu“ suundumustest ja mutatsioonidest või abstraktse ,inimvaimu“" maadlemisest üleajalooliste metafüüsiliste probleemidega. ${ }^{74}$ Seevastu on Jaan Undusk oma mõtet-ärgitavates esseedes kasutanud väga ulatuslikku meetodite arsenali, mille hulka kuuluvad nii kontekstitundlik tekstianalüüs ${ }^{75}$ kui ka vaimuajaloolist laadi käsitlusviis, mille juures on teadlikult loobutud vaadeldava autori enda käsutuses olnud mõisteaparaadi uurimisest või tema intentsiooni rekonstrueerimisest, vaid autor on paigutatud laiemasse üldfilosoofilisse skeemi või ideoloogilisse põhimustrisse, millest too ise ei pruukinud teadlikki olla. ${ }^{76}$ Äärmuslikel juhtudel võib see viia autoritele selliste metafüüsilist laadi eesmärkide omistamiseni, mis on lausa vastupidised nende teadvustatud kavatsustele. Nii on Unduski otsinud hegelliku ,iseseisvuse idee“ või „autonoomsusteadvuse" kandjaid Eesti ala varasemast ajaloost ning jõudnud provokatiivsete järeldusteni, et ordumeister Goswin von Herike, Carl Schirren ja Carl Robert Jakobson võitlesid kõik ,ühisbalti solidaarsuse“ raames ,mingil üldisemal tasemel“ Eesti omariikluse idee eest. ${ }^{77}$ Ajaloolased on seepeale kutsunud üles pöörduma „tagasi aja-

${ }^{71} \mathrm{Nt}$ artiklid kogumikus „Iseseisvusmanifest: Artikleid, dokumente ja mälestusi“.

${ }^{72}$ Piirimäe, P. Just war in theory and practice: The legitimation of Swedish intervention in the Thirty Years War. - The Historical Journal, 2002, 45, 3, 499-523; Piirimäe, P. Russia, the Turks and Europe: Legitimations of war and the formation of European identity in the early modern period. Journal of Early Modern History, 2007, 11, 63-86; Piirimäe, P. War and polemics in early modern Europe. - Exploring cultural history: Essays in honour of Peter Burke. Ed. by M. Calaresu, F. de Vivo, J.-P. Rubies. Ashgate, Aldershot, 2010, 133-149.

${ }^{73}$ Piirimäe, P. Johann Reinhold von Patkuli poleemilised kirjutised. - Läänemere provintside arenguperspektiivid Rootsi suurriigis 16/17. sajandil. Koost E. Küng. (Eesti Ajalooarhiivi toimetised, 17 (24).) Eesti Ajalooarhiiv, Tartu, 2009, 155-187; Piirimäe, P. The capitulations of 1710 in the context of Peter the Great's foreign propaganda. - Die baltischen Kapitulationen von 1710, 65-86; Piirimäe, P. Livonian Vaterland and Swedish Landesvater: Languages of patriotism in the seventeenth-century Swedish Empire. - Politische Dimensionen der deutschbaltischen literarischen Kultur, 15-45.

${ }^{74}$ Vene, I. Ristiusu mõistatus: Jumalinimesest inimjumalani. Patmos, Tallinn, 2009, 27; vt ka Vene, I. Pahustumine ehk uusaja olemus. Ilmamaa, Tartu, 2002. Retsensioonid: Paul, T. Pahupidi puu. Sirp, 09.08.2002; Lahe, J. Sekulariseerimise mõistatus. - Sirp, 19.03.2010.

${ }^{75}$ Undusk, J. „Esimene eesti juudiõgija“: Ado Grenzsteini endatapp antisemitismis; Undusk, J. Eesti Pindaros: Kristjan Jaak Petersoni oodide vaimuloolisest taustast [2012]. - Undusk, J. Eesti kirjanike ilmavaatest. (Eesti mõttelugu, 118.) Ilmamaa, Tartu, 2016, 66-113; Undusk, J. Iseseisvusmanifesti intertekstuaalsus. - Iseseisvusmanifest, 19-52.

${ }^{76}$ Undusk, J. Kolm võimalust kirjutada eestlaste ajalugu: Merkel - Jakobson - Hurt [1997]. - Undusk, J. Eesti kirjanike ilmavaatest, 169, 184; Undusk, J. Eksistentsiaalne Kreutzwald [2004]. - Undusk, J. Eesti kirjanike ilmavaatest, 114.

${ }^{77}$ Undusk, J. Ajalootõde ja metahistoorilised žestid: Eesti ajaloo mitmest moraalist. - Tuna, 2000, 2, 114-130 (tsitaadid lk 114, 120, 128). 
lukku“, s.t „metahistoorilise“ käsitlusviisi juurest histoorilise ehk ajaloolise seletuse juurde. ${ }^{78}$ See vaidlus osutab üsna selgele metodoloogilise eritlemise võimalusele vaimuajaloo ja intellektuaalajaloo vahel. Viimane püüab vältida ajaloolistele tegutsejatele „,õpptulemusest“ lähtuva teleoloogilise funktsiooni omistamist või nende mõtete taandamist sellise funktsiooni kandmisele, ${ }^{79}$ uurides hoopis tegutsejate teadvustatud ideid ja taotlusi konkreetses ajaloolises kontekstis. Ent kahtlemata viivad erinevatest meetoditest tulenevad ,ajalootülid“ Eesti mõtteloo sügavama läbitunnetamiseni.

Teine võimalus Eesti mõtteloo alast uurimistööd liigitada on žanrist lähtuv. Ülekaalukalt domineerivaks žanriks on olnud biograafia, mille viljelemist on soodustanud nii laiema publiku huvi kui ka institutsionaalsed tellimused. ${ }^{80} \mathrm{Nii}$ on biograafilise žanri juurde siirdunud hulk teadlasi, kes oma väitekirjad või varasemad teadustööd kirjutasid spetsiifilisest uurimisteemast, mitte ajaloolise isiku eluloost lähtuvalt. ${ }^{81}$ Mõtteajaloo osakaal nendes uurimustes on väga erinev, sõltuvalt sellest, kas käsitletav ajalooline isik pühendus peamiselt kirjamehe või teadlase karjäärile või oli tekstide kirjutamine ühiskondliku tegutsemise juures pigem kõrvalprodukt. ${ }^{82}$ Viimasel juhul võib kõnelda tavabiograafia ja intellektuaalse biograafia kombinatsioonist, kus mõtteajaloolised uurimisküsimused pakuvad huvi niivõrd, kuivõrd need aitavad seletada protagonisti tegutsemismotiive.

${ }^{78}$ Brüggemann, K. Rahvusliku vaenlasekuju demontaažist ehk Carl Schirren kui Eesti iseseisvuse rajaja? - Tuna, 2002, 3, 93-98. Jansen, E. Tagasi ajalukku. - Tuna, 2003, 2, 131-136.

${ }^{79}$ Seda teeb Undusk eksplitsiitsemalt oma vastuses kriitikale: Undusk, J. Eesti ajaloo kotkaperspektiivist: Minu vaidlus Brüggemanniga. - Tuna, 2002, 3, 99-116.

${ }^{80} \mathrm{Nt}$ Tartu Ülikooli tellitud rektoriraamatute sari (Kalling, K. Rektor Henrik Koppel. Aasta Raamat, Tallinn, 2007; Rohtmets, P. Rektor Johan Kõpp. Aasta Raamat, Tallinn, 2007; Kalling, K. Rektor Hugo Kaho. Aasta Raamat, Tallinn, 2009; Kivimäe, J. Rektor Hans Kruus. Aasta Raamat, Tallinn, 2017; Kalling, K. Rektor Jüri Kärner. Aasta Raamat, Tallinn, 2019), samuti Rahvusarhiivi Eesti riigivanemate ja peaministrite sari Riigikantselei stipendiumi toel (statuut vt https://www.riigikantselei.ee/et/stipendium); sarjas on ilmunud Ant, J. August Rei: Eesti riigimees, poliitik, diplomaat. Rahvusarhiiv, Tartu, 2018; Paavle, I. Õiguse ja omariikluse eest: Otto Tief. Riigiarhiiv, Tartu, 2014; Karjahärm, T., Pajur, A. Konstantin Päts: Poliitiline biograafia I: Vabameelne opositsionäär (1874 1916); II: Riigimees (1917-1956). Rahvusarhiiv, Tartu, 2018; Aru, K. Jaan Tõnisson: Rahvajuht ja riigivanem 1-2. Rahvusarhiiv, Tartu, 2019). Ka mujal maailmas on see jätkuvalt levinud žanr mitte ainult populaarteaduslike käsitluste puhul, näiteks on 2018. aastal ametisse astunud Cambridge'i Ülikooli poliitilise mõtte ajaloo professori Richard Bourke'i peateos intellektuaalne biograafia Edmund Burke'ist: Bourke, R. Empire and revolution: The political life of Edmund Burke. Princeton University Press, Princeton, NJ, 2015.

${ }^{81} \mathrm{Nt}$ Aru, K. Jaan Tõnisson - rahvajuht ja riigivanem; Karjahärm, T. Konstantin Päts: Poliitiline biograafia I: Vabameelne opositsionäär (1874-1916); Kivimäe, J. Rektor Hans Kruus; Salupere, M. Postipapa: Mitmes peeglis, mitmes rollis. Tänapäev, Tallinn, 2006. Salupere, M. Koidula: Ajastu taustal, kaasteeliste keskel. Tänapäev, Tallinn, 2017; Tohvri, E. Georges Frédéric Parrot: Tartu Keiserliku Ülikooli esimene rektor. Tartu Ülikooli Kirjastus, Tartu, 2019. Ka Mart Laar, kelle väitekiri uuris ärkamisaja aktiviste laiapõhjaliselt (Laar, M. Äratajad: Rahvuslik ärkamisaeg Eestis 19. sajandil ja selle kandjad. Eesti Ajalooarhiiv, Tartu, 2005), on hiljem siirdunud populaarsemas laadis biograafiate juurde: Laar, M. Raamat Jakob Hurdast. Ilmamaa, Tartu, 1995; Laar, M. Johann Voldemar Jannsen: Elu ja töö. Read, Tallinn, 2019.

${ }^{82}$ Mõtteajaloo osatähtsus on suur Hupeli (Jürjo, I. Liivimaa valgustaja A. W. Hupel 1737-1819) ja Parrot', aga ka Kruusi biograafias, mõnevõrra vähem kaalukas Jannseni, Tõnissoni või Pätsi elulooraamatute puhul (vt viited 80 ja 81 ). 
Biograafilise meetodi eeliseks on asjaolu, et see võimaldab terviklikult esitada ühe isiku vaadete kujunemist ja arengut. See on kindlasti atraktiivne ka lugeja seisukohalt, pakkudes lisaks intellektuaalsele mõtestamisele võimaluse emotsionaalseks kaasaelamiseks. Siiski kaasneb oht, et oma teose protagonistiga liigselt samastuv autor libastub hagiograafilisse käsitlusviisi, mis võib saada takistuseks kriitilisele analüüsile. ${ }^{83}$ Teiseks ohuks on kangelase isoleerimine teda mõjutanud kontekstist ning ajaloo interpreteerimine suurmeeste mõtlemise ja tegutsemise tulemina Thomas Carlyle'i kangelasajaloo võtmes. ${ }^{84}$ Biograafilise meetodi pea paratamatust hermeetilisusest aitab üle saada kollektiivse intellektuaalse biograafia žanr, mis võimaldab paremini rekonstrueerida ajastu ideoloogilisi erimeelsusi ja vaidlusi. ${ }^{85}$

Intellektuaalse biograafia kaudu on võimalik ajastu ideestikust anda küllaltki mitmetahuline ja elav pilt, ent terviklikuma mõtteajaloolise käsitluse taotlemise korral võib see žanr muutuda piiravaks ning produktiivsemaks osutub mõtteloo uurimine laiema autorite ja tekstide valiku põhjal. ${ }^{86}$ Oluline on sealjuures vältida kahte levinud kari. Esiteks metodoloogiline natsionalism ehk isoleeritud genealoogiad. Eesti mõtteloo autoreid uurides on pööratud tähelepanu nende kodumaisele ning sageli ka Baltimaade ja impeeriumi kontekstile, aga senisest rohkem oleks tarvis uurida, kuidas nende vaadete kujunemist on mõjutanud laiema Euroopa ja muu maailma ideed, debatid ja sündmused. Ideeliste laenude ja laenatu omakstegemise uurimise tööpõld on jätkuvalt lai. Metodoloogilise rahvusluse väljenduseks on olnud ka eesti ja (balti)saksa mõtteloo mõningane vastastikune isoleeritus, ${ }^{87}$ millest ülesaamiseks saaks edukalt rakendada Jaan Unduski „maiskondlikku“ printsiipi ilma selle hegellike ülemtoonideta. ${ }^{88}$ Teiseks kariks on sildistamise harjumus, mille all ma pean silmas ajalooliste autorite ideede sisulise analüüsimise asemel nende

${ }^{83}$ Üheselt kaasaelavad teosed on nt: Aru, K. Jaan Tõnisson; Laar, M. Johann Voldemar Jannsen; Tohvri, E. Georges Frédéric Parrot. Vt sarnane kriitika: Marchand, S. Has the history of the disciplines had its day? - Rethinking modern European intellectual history, 131-152.

${ }^{84},[. .$.$] all things that we see standing accomplished in the world are properly the outer material result,$ the practical realization and embodiment, of Thoughts that dwelt in the Great Men sent into the world." (Carlyle, T. On heroes, hero-worship, and the heroic in history [1840]. https://www.guten berg.org/files/1091/1091-h/1091-h.htm (20.06.2020)), „Suurmeeste“ biograafiate žanri kaitseks vt: Richards, R. J. The role of biography in intellectual history. - KNOW: A Journal on the Formation of Knowledge, 2017, 1, 2, 295-318.

${ }^{85}$ Eestis nt Valge, J. Punased I. Tallinna Ülikooli Eesti Demograafia Instituut, Rahvusarhiiv, Tallinn, 2014.

${ }^{86} \mathrm{Nt} \mathrm{T}$. Karjahärmi teosed (vt viide 12).

${ }^{87}$ Neid seoseid on tugevamalt välja toodud teadusajaloolaste töödes, nt: Tammiksaar, E. Alexander Theodor von Middendorffi tegevus Liivimaa põllumajanduse edendajana ning tema seosed eesti rahvusliku liikumisega. - Eesti Ajalooarhiivi toimetised. Toim T. Tannberg. Eesti Ajalooarhiivi Kirjastus, Tartu, 2006, 157-211. Jannseni, Hurda, Jakobsoni jt toetumist saksa (ja laiema Euroopa) mõtteloo eri traditsioonidele on vaid markeeritud, aga mitte süstemaatiliselt uuritud.

${ }^{88}$ Marek Tamm ja Kalevi Kull on selles vaimus kutsunud üles kultuuriteooria ,reterritorialiseerimisele“ ning lansseerinud „Eesti teooria“ kui lokaalse episteemi idee: Tamm, M., Kull, K. Eesti teooria. - Akadeemia, 4, 2015, 579-625; Tamm, M. Kull, K. Toward a reterritorialisation of cultural theory: Estonian theory from Baer via Uexküll to Lotman. - History of the Human Sciences, 2016, 29, 1, 75-98. 
autorite suurte ideoloogiliste ismide alla paigutamist, kusjuures need sildid on sageli „tühjad tähistajad“ ehk liiga üldised, et uuritavate ideede kohta midagi substantsiaalset öelda, või on tegemist hilisemast perioodist pärinevate anakronistlike kategooriatega. ${ }^{89}$

Mõlemat kari on võimalik paremini vältida, kui pöörata rohkem tähelepanu mõisteajaloolisele uurimistööle. Nii nagu Koselleck ja ta kolleegid uurisid modernse sõnavara kujunemist Sattelzeit' 'i aegsel (1750-1850) Saksamaal, vääriks põhjalikku uurimist eestikeelse ühiskondlik-poliitilise sõnavara loomine, laenamine ja tähendustega täitmine 19. sajandi teisel poolel ja 20. sajandi algul. Näiteks võib tuua sellised sõnad nagu ,seltskondlik“, ,ühiskondlik“, ,,ühiseluline“; ,rahvas“, ,rahvus“ ja selle tuletised; „loomus“, „loodus“; „õigus“, „õiglus“; ,,tsivilisatsioon“", „,kultuur“; „orjus“, ,,priius“", „vabadus“, ,ajalugu“, ,progress“, ,,enesemääramine“, ,,autonoomia“, „,iseseisvus“, „,demokraatia“, aga ka needsamad ismid, nagu „liberalism“, „konservatism“ ja „sotsialism“. Loomulikult ei ole need mõisted sellest ajast peale staatilisena püsinud, vaid intellektuaalajaloo üks põnevamaid ülesandeid ongi selle uurimine, kuidas ajaloolised tegutsejad minevikust päritud mõistetega ringi käivad ja neid uute tähendustega täidavad. ${ }^{90}$

\section{KOKKUVÕTTEKS}

Eesti mõtteajaloos on 21. sajandil märgata rõõmustavat temaatilist ja metodoloogilist mitmekesisust, mistõttu uurimispõllu seisu kokku võtta pole lihtne ülesanne. Usinalt on edasi küntud juba varem kõige hoolsamalt haritud maalappi, aga samas on tähelepanu leidnud ka mitmed varem sööti jäetud põllusiilud. Esimese all pean silmas 19. sajandi teise poole ja 20. sajandi alguse Eesti mõttelugu, mille uurimine on olnud kantud huvist selgitada iseseisva riigi loomiseni viinud rahvusteadvuse ja -ideoloogiate kujunemist ja arengut. Aga nagu näitavad eespool mainitud uurimisprojektid ja nooremate teadlaste huvi, ${ }^{91}$ ei ole see teemadering end sugugi ammendanud, vaid pakub jätkuvalt võimalusi mitmesuguste mõttelooliste arenguliinide uurimiseks avaramas rahvusvahelises kontekstis. Teisalt on varasemate perioo-

\footnotetext{
${ }^{89}$ Levinumateks tühjadeks tähistajateks on „liberalism“ ja „konservatism“. Nt Parrot’ nimetamine „,veendunud liberaaliks“ on ähmane või lausa eksitav (vt ka arvustus Piirimäe, P. Epi Tohvri, Georges Frédéric Parrot: Tartu Keiserliku Ülikooli esimene rektor. - Ajalooline Ajakiri, 2019, 3/4 (169/170), 423-428); Hupeli kohta on I. Jürjo kasutanud oksümoroonilisi „liberaal-konservatiivne“ ja „,reformikonservatiivne“" (Jürjo, I. August Wilhelm Hupel, 418.)

${ }^{90}$ Väärib märkimist, et mõisteajaloo uurimine on eriti tugeval järjel Soomes: 1998. aastal asutatud History of Political and Social Concepts Group'i üheks algatajaks oli Kari Palonen (Jyväskylä Ülikool) ning Helsingi Ülikooli intellektuaalajaloo keskus (University of Helsinki Centre for Intellectual History) annab välja ajakirja Contributions to the History of Concepts.

${ }^{91}$ Allakirjutanu (kaas)juhendatavad doktorandid, kes seda perioodi uurivad: Timo Aava, The adaptation of the concept of non-territorial autonomy in Estonia 1900-1940 (Viini Ülikool, juh B. Kuzmany, P. Piirimäe); Margo Roasto, Rahvusküsimus ja maareformikavad duumamonarhia ajajärgul: Ühiskondlik mõte Eesti alal 1905-1917 (Tartu Ülikool, juh P. Piirimäe). Vt ka Roasto, M. The political debate about the land question in the Estonian area of the Baltic provinces, 1905-1914. Journal of Baltic Studies (04.05.2020). DOI: 10.1080/01629778.2020.1748074.
} 
didega võrreldes oluliselt rohkem tähelepanu pälvinud Läänemere provintside varasem, peamiselt ladina- ja saksakeelne mõttelugu, mille uurimise juures on mõtteja kultuuriajaloolased teinud head koostööd klassikaliste filoloogide, kirjandusteadlaste, teadusajaloolaste, teoloogide jt lähedaste distsipliinide esindajatega.

Loomulikult on tööpõld jätkuvalt lai ning ammendavat nimekirja uurimist väärivatest teemadest pole võimalik esitada, seda enam, et tulevaste uurijate huvid ja rahastajate prioriteedid sõltuvad nii teaduste kui ühiskonna arengust. Minu subjektiivsetest eelistustest lähtuvalt vajaks põhjalikumat uurimist valgustusfilosoofia retseptsioon Balti provintsides, mis on oluline nii 19. sajandi alguse reformide taustana kui ka „ärkamisaja“ ideoloogiate filosoofilise tagapõhjana. ${ }^{92}$ Samal ajal on seda ajastut Eesti historiograafias käsitletud ilmselt liiga sekulaarsest perspektiivist ning pietismi ja saksa vagaduskirjanduse mõju nii eesti kui saksa soost rahvavalgustajatele vajab samuti täiendavat tähelepanu. Tulles hilisemate perioodide juurde, siis on näiteks rahvusideoloogiate areng sõdadevahelises vabariigis, mõistagi paigutatuna tollasesse dünaamilisse rahvusvahelisse intellektuaalsesse konteksti, teema, mille ammendamiseks ei piisa mitmest doktoritööst. ${ }^{93}$ Aga ka nõukogude perioodi ideoloogiad ning ideologiseeritud ja repressiivse ühiskonnaga kaasnevad kollaboratsiooni, kohanemise ja vastupanu strateegiad on oluline, aga seni väheuuritud temaatika. ${ }^{94}$ Viimastel aastatel on ,ajaloostunud“ ka iseseisvuse taastamise periood, mille mõtteloolised aspektid on pälvinud mitme noorema generatsiooni ajaloolase tähelepanu. ${ }^{95}$

Mõtteajalugu ei ole kompaktne ja selgepiiriline valdkond, vaid alatasa otsiv ja ennast uuesti leiutav, et mitte öelda „,distsiplineerimatu“ distsipliin. Range metodoloogilise kaanoni kehtestamine võiks mõjuda kahjulikult senisele vaatenurkade rohkusele. Samas on teatav metodoloogiline järjepidevus ja uurimuslik sihiseade vajalik, et kindlustada positsiooni iseseisva teadusvaldkonnana. ${ }^{96}$ Arusaam, et kõik

92 Üks oluline teemaliin on tsivilisatsiooni ja progressi idee, mida uurib doktorant Kadi Kähär-Peterson: „Inimsoo progress, Euroopa ja Baltikum: Garlieb Merkeli (1769-1850) ideed Euroopa tsivilisatsiooniteooriate kontekstis“ (Tartu Ülikool, juh E. Piirimäe, P. Piirimäe).

93 Seda teemat uurib praegu doktorant Liisi Veski: ,The concept of national unity in the interwar Estonian nationalist discourse“" (Glasgow' Ülikool, juh D. Smith, P. Piirimäe).

${ }^{94}$ Selle teemavaldkonna eri tahke on viimastel aastatel uurinud Tõnu Tannberg: Tannberg, T. „Üks võimsamaid relvi võitluses kodanlise natsionalismi vastu on kindlasti eesti ajalugu...": Eesti vabariigi perioodi uurimisest Eesti NSV Teaduste Akadeemia ajaloo instituudis aastatel 1946-1950. Ajalooline Ajakiri, 2018, 2/3 (164/165), 203-224; Tannberg, T. ,,Tsensuuri töö on väga vastutusrikas“: Dokumentaalne pilguheit Eesti NSV Glavliti tegevusele aastatel 1941-1948. - Ajalooline Ajakiri, 2018, 166, 4, 337-353. Vt ka üldkäsitlus: Karjahärm, T., Sirk, V. Kohanemine ja vastupanu: Eesti haritlaskond 1940-1991. Argo, Tallinn, 2007.

95 Nt Piirimäe, K., Grönholm, P. Historical consciousness, personal life experiences and the orientation of Estonian foreign policy toward the West, 1988-1991. - Ajalooline Ajakiri, 2016, 3/4 (157/158), 477-511; Saharov, J. An economic innovation as an icebreaker: The contractual work experiment in Soviet Estonia in 1985. - The Baltic states and the end of the Cold War. Ed. by K. Piirimäe, O. Mertelsmann. (Tartu Historical Studies.) Peter Lang, Frankfurt am Main, New York, 2018, 65-84.

${ }^{96}$ Euroopa teadusvaldkondade ja -erialade klassifikaatoris (Common European Research Classification Scheme (CERCS) eraldiseisev intellektuaalajaloo valdkond puudub, aga positiivse märgina on see eraldi lahtrina ERC grantide hindamise paneelide jaotuses (SH6_10 History of ideas, intellectual history, history of sciences and techniques). 
ajaloolased või lausa kõik humanitaarteadlased uurivad ka mõttelugu, kõlab uhkelt, aga see võib ka tähendada, et õieti keegi ei pööra sellele piisavalt tähelepanu. Siiski näib, et vaatamata hilisele emantsipeerumisele 20. sajandil on mõtteajalugu leidnud endale 21. sajandil selge koha Eesti teadusmaastikul.

\section{TÄNUSÕNAD}

Artikli valmimist on toetanud Eesti Teadusagentuuri grant PRG318 „Ümberkorraldustele aluste loomine: Muutuste poliitilised ja majanduslikud argumendid Läänemere ruumis varauusajal" ning see on seotud Euroopa Liidu Regionaalarengu Fondi toetatud Eesti-uuringute Tippkeskusega ja Eesti Haridus- ja Teadusministeeriumi uurimisprojektiga IUT20-5.

\section{INTELLECTUAL HISTORY IN ESTONIA IN THE TWENTY-FIRST CENTURY}

\section{Pärtel PIIRIMÄE}

The article aims to survey the research on intellectual history in Estonia during the first two decades of the 21st century. In order to appreciate the current institutional status of the discipline and its state of research, the first part of the article gives a short overview of the earlier history of the research field in Estonia against the background of the developments elsewhere in the world. The history of ideas or intellectual history emancipated as a distinct field of study in Sweden and the United States in the 1930s, and gained broad acceptance at universities in Western countries after World War II. Although in Estonia scholarly interest in the ideas of the past can be traced back to the early 20th century, the development of the discipline was hindered by the long period of the Soviet occupation, when materialist MarxistLeninist doctrine as the only acceptable interpretation of history was enforced. Nevertheless, despite ideological pressure and censorship, progress was made in various aspects of the earlier intellectual history in Estonia, such as the history of education and science, or the ideas of the 'national awakeners' in the 19th century.

Since the regaining of independence in the 1990s, intellectual history as an academic research field has gained an increasingly important status in Estonian academia, which can be explained by four factors. Firstly, historians who started their careers in the Soviet period were able to publish the results of their lifelong research without censorship. Secondly, a new generation of historians has emerged who have received their degrees in various European centres of the study of intellectual history, and have upon their return initiated similar research and teaching at Estonian universities. Thirdly, there has been a notable shift in neighbouring disciplines of the humanities towards questions and approaches characteristic of intellectual history, among them literary studies, classical studies, religious studies, history of 
science, art history, history of law, etc. Intellectual history has often functioned as the meeting point for these fields in a situation in which interdisciplinary cooperation has been enhanced both by the smallness of Estonian academia and the preference of funding bodies for large-scale projects. Fourthly, the key texts by historical authors have been made easily available to the general public, which has increased general interest and facilitated teaching and research in intellectual history. Most important among these is the History of Estonian Thought (Eesti mõttelugu) book series published by Ilmamaa, although one should also note the digital databases developed by Tartu University Library and the National Library of Estonia. As a result of these factors, in the early 21 st century several academic positions in the field of intellectual history, the history of political thought and political philosophy have been created at the Universities of Tartu and Tallinn.

The article outlines the main methods and genres that have been employed in research in intellectual history over the past two decades. One can notice a rich variety of approaches, which are not easily reduced to a clear catalogue, particularly since the scholars have not always been explicit about their methods or have used a mixture of methods. However, it seems possible to distinguish between the scholarship which, influenced by the contextualist method advanced by the Cambridge school, attempts to reconstruct the intentions of the historical authors in the particular pragmatic and ideological contexts of their era, and scholarship that studies the 'spirit of the age' or the emanation of some transcendent ideas across swathes of time, perhaps influenced by the German tradition of Geistesgeschichte or the Lovejoyan school of the history of ideas. With regard to genres, the (intellectual) biography has been the preferred choice, although there are also examples of collective biographies and thematically-oriented books.

The article concludes with a discussion of possible methodological pitfalls associated with certain methods and genres, and with a sketch of potential avenues for future research. 